\title{
Shifting of values and perspectives in the new normal
}

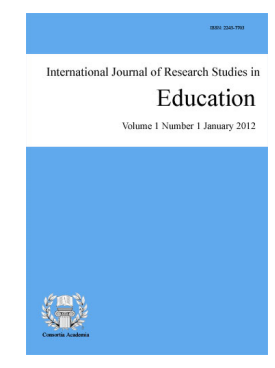

Rabina, Lailanie $\$

Laguna College of Business and Arts, Philippines (lailanie.rabina@deped.gov.ph)

\section{Abstract}

This study was conducted to explore the day-to-day journey of public secondary teachers in the new normal and how they can cope with all the challenges they encounter in order to ensure that their values and perspectives are intact. The participants of the study were composed of fifteen (15) teachers from across nine (9) departments of Lecheria Integrated School who experienced some changes in their values and perspectives in this new normal set up of education in the Cluster 5 Division of Calamba. This study utilized the qualitative research, specifically the Phenomenological Approach. In the conduct of this qualitative research, the researcher used the purposeful random sampling. Using the guide questions, the researcher conducted her interviews online via Google Meet. The themes that emerged from the participants of the study were unanimous with regards to the shifting of values and perspectives in the new normal in education. The participants' positive well-being contributed to addressing the challenges of the new normal education. Encouraging outlook, self-confidence gained from encouragement and motivation, healthy lifestyle, and stress reduction allowed them to continue performing their duties and responsibilities despite the challenges of these trying times. Similarly, the summarized findings from the responses in the interviews were discussed in relation to theories and other research findings from the gathered literature. The significance of acknowledging these findings was that teachers were willing to adjust and adapt to the new pedagogical landscape. Teachers exerted everything to the fullest so as to cope with the new normal setup of the education process.

Keywords: education, shifting, values, perspectives, new normal 


\section{Shifting of values and perspectives in the new normal}

\section{Introduction}

Education is key for generations of Filipinos to become full-fledged, productive members of society. Teachers play an important role in our life to become successful in career and business. They are the ones who help us to become a good human being and a good citizen of the country. Teachers know that students are the future of any nation. So, the future development of any nation is in their hands. The appreciation for them is very important because they are one of the most important people in the country. But no matter how their image is as what the community expects, the fact is that teachers, are human too. They do not have "superpowers" to use so they will not get tired, bored, annoyed or feel bad about themselves.

In this time today, as everyone faces this pandemic, even in other countries, teachers struggle, too. In fact, when COVID-19 came here in the Philippines and it becomes rampant, the Department of Education in order to ensure that learning will take place even though we have this crisis, still provides an appropriate answer on the issue of the school opening for SY 2020-2021. They conducted consultations with its executive committee, management committee, civil society, business sector and education experts. Parents and learners also expressed their views on Facebook, and other forms of social media.

Moreover, the Department of Education (DepEd) accelerates the preparation of Learning Continuity Plan (LCP), prepares benefits for the non-teaching and teaching staff, ensures the readiness and cleanliness of school's infrastructure and develops alternative delivery modes of learning. DepEd Secretary Leonor Magtolis Briones, in one of her statements, assures that learners, parents, teachers and public, to make for the continuation of learning, will have their health, safety and wellbeing take into primary consideration. It has not been an obstacle for the department to continue the school year. DepEd came up opening this school year prospecting to the combined studies on how to overcome demands amidst this pandemic. The department was not shaken to officially open the academic year 2020-2021 for 47,000 public schools all over the country through this what we call "blended education".

Accordingly, there were lots of orientations, webinars, dry runs, and planning for the delivery of learning resources to ensure a successful opening of classes. What is a teacher's role in the "new normal"? Saint Francis of Assisi College stated that it is not only the schools, curriculum, and the learners who have to undergo changes in transitioning to blended learning. Teachers are also moving forward from traditional to adaptive learning. Although there are lots of things similar between the traditional and blended learning set-up when it comes to curriculum and delivery, there are new things as well.

Because of this, there are new roles that teachers need to embrace to grow professionally and to effectively teach despite of changes. Teachers need to upskill themselves to stay abreast of emerging technology and skills to attend the needs of the learner and make sure that the quality of learning remains even with the absence of face-to-face interactions. Teachers have been finding ways to continue students' learning process, refusing to give up on their calling even amid the pandemic, it is sad to say that teachers are being judged instantly, being bashed in social media because of little mistakes. Although experiencing and hearing this kind of news is not new already still it hurts, still leaves an "incredible" mark to how the people think of a teacher. I think some people do not see their effort playing the role being a parent to the youth. Some teachers are not techie, but still try their best ways to learn and adapt to the demands of the new normal. Above all, teachers are ready forgetting even their own health concerns just to serve people in this pandemic because they believe it is their duty as public servants.

Indeed, it is important for teachers to be committed and motivated. Specifically, in an article published last February 7, 2017, it was stated that a motivated teacher is crucial to a successful learning inside the classroom 
and even in this modular distance learning, they will look at teaching through a different lens, and in doing so, motivate their students in their learning too. Motivation helps to energize, direct and sustain positive behavior over a long period of time. According to Maiyani (2017), passion generates commitment and commitment motivates and inspires the teachers. It is an inspiring factor that affects teacher performance. It drives a teacher for a better student accomplishment. Truly, passionate teachers create an effective learning environment and increase learning potential of students. The challenges under the new normal mode of education experienced by the teachers, the "disturbing" changes of their values and perspectives and how this new experience could lead to insights and better learning opportunities pushed the researcher to further study the lived experiences of secondary school teachers. The lives of people, including the lives of young people are drastically changing. The implementation of different

\subsection{Theoretical Framework}

The study was anchored in the Transactional Theory of Stress and Coping, developed by Lazarus and Folkman (1987). They defined this theory as a framework which emphasizes appraisal to evaluate harm, threat, and challenges, which results in the process of coping with stressful events. It evaluates how major life events and daily hassles impact on emotions with the emphasis on cognitive appraisal and coping with stress. Also, cognitive appraisal consists of primary appraisal, which is to assess the harm or threat the situation may pose, and secondary appraisal, which evaluates what can be done and the individual's ability to manage and cope with it. Coping follows from this appraisal of threat and can influence either a change in the person-environment relationship or the level of emotional distress experienced. Personality traits, depressive symptomology and social support are some factors which influence coping skills and abilities. Cognitive behaviors therapies and approaches enable individuals to identify and become aware of thoughts and feelings that lead to inadequate coping and learn new ways to problem and cope.

According to Lazarus (1986) and Lazarus and Folkman (1987), the most used transactional theory suggests that stress is the direct product of a transaction between an individual and their environment which may tax their resources and thus threaten their wellbeing. Yet a more recent version of this theoretical model suggested that it is the appraisal of this transaction that offers a casual pathway that may better express the nature of the underlying psychological and physiological mechanisms which underpin the overall process and experience of stress. Lazarus in his transactional model of stress and coping stated that stress is experienced when a person perceives that the "demands exceed the personal and social resources the individual is able to mobilize."

Hobfoll (1989), on the other hand, also believed that stress is a major factor which not only affects people's lives, but also has an impact on their mental and physical health. Lazarus and Folkman (1984) attributed stress stimuli to two types of events: major life events and daily hassles. Major life events such as changes can be divided into two categories. The first are environmental (natural) events that are unforeseen and unpredictable and outside a person's control such as cataclysmic phenomena like earthquakes, floods or bushfires that affect many people, pandemic like COVID-19 as well as other not naturally occurring disasters such as war, airplane disasters, and tragedies such as terrorist attacks. The second type of major life event are those which, although also outside of a person's individual control, affect only a few people, and can include events such as the death of a loved one, divorce, disability, or a life-threatening illness.

Still in connection, life events cannot be considered as the sole measure of stress and not all change is stressful. Lazarus and Folkman (1984) identified that the personal significance of the event is critical and depends on the affected person's history, life stage and circumstances and that each event, whether major or minor, leads to an individual experience with individual meaning in the way it is interpreted on a day-to-day basis. The second one is daily hassles. They suggested that daily hassles, which often appear unimportant in relation to major life events, and therefore can often be taken for granted, which can be stressful. Daily hassles are those experiences that can lead to annoyance, irritation, and distress, and ultimately in feeling overwhelmed by responsibilities, and can include having an argument, money and family worries. 
In addition, they emphasized that daily hassles are usually repeat occurrences, and are superior in predicting psychological and physical symptoms, accounting for almost all attributable stress, whereas life events have almost no impact. They give a concrete example by describing the difference between the sudden death of someone in a motor vehicle accident to that experienced from death after a long period due to a terminal illness. Even though the loss is equally stressful, the degree of the stress experience differs over time. Moreover, they asserted that stress can cause feelings of anxiety, depression, changes in behavior and physiology, as well as acute and chronic illness, increasing the likelihood of addictions such as drugs, alcohol and eating, and is particularly evident because of daily stresses. DeLongis et al. (1982) found out that the frequency and intensity of daily hassles related to somatic illness, and this relationship was stronger than for life events. The meaning and significance of hassles depends on the individual's appraisal based on life experience, commitments, and expectations, and how these interact with the actual event. Effectively daily stresses can be as damaging as major life events and can potentially leave an individual vulnerable to anxiety, depression, and changes in behavior.

Most of the people have ways of dealing with the pressures of work, such as an online gaming, a stroll, going to the gym and of so many others. However, they do not know if these strategies will help or hinder the ability to stay focused and motivated at work. Many researchers hope to find out how people deal with stress at work and relax and unwind from the daily grind and whether these coping mechanisms improve wellbeing. Accordingly, Lazarus and Folkman (1987) pointed out that coping arises from appraisal that the demands of an event exceed personal resources and is motivated by the emotional response to harm and threat. This appraisal serves two primary functions: to change the person-environment relationship and to influence the level of emotional distress. In addition, coping comprises the cognitive and behavioral efforts required to manage the internal or external environment when a level of dissonance exists in a person's perception of their ability and resources to deal with the psychological stress.

Definitely, coping can be defined by the relationship between the person and the environment and depends on subjective well-being, social functioning, and somatic health, as well as the relevance placed on these by the individual at any given time. With this, Lazarus (1993) explained that this relationship is constantly changing from one time to another and can be seen in the complex stages of an examination, where students go through a warning period, a confrontational stage or exam, and a waiting period for results, all of which require different coping strategies. This theory supported how the teachers strengthens their self-efficacy to handle and cope with the challenges in the new normal and in the next years to come that will help them to be a better person in the profession that they embraced.

\subsection{Research Design}

This study utilized the qualitative research, specifically the Phenomenological Approach. According to Creswell (2014), qualitative research is an approach for exploring and understanding the meaning individuals or groups ascribe to a social or human problem. Moreover, phenomenological research is a design of inquiry coming from a philosophy and psychology in which the researcher described the lived experiences of individuals about a phenomenon as described by participants (Moustakas 1994, as cited in Giorgi, 2009). Likewise, in qualitative approach one of the key elements of collecting data in this way is to observe participants' behaviors during their engagement in activities. Researchers record information from interviews by making handwritten notes, by audiotaping, or by videotaping (Creswell, 2014). Gathered data will be summarized to analyze the phenomenon being studied.

In this study, the researcher used this design which is truly appropriate since she aimed to explore the topic as well as experiences of the participants involved in this study. She utilized the Interpretative Phenomenology Analysis (IPA) and explored in detail the individual personal and lived experiences and examined how participants were making sense of their personal and social world. Different interpretative stances were possible and IPA combined empathic hermeneutics with a questioning hermeneutics. Thus, consistent with its phenomenological origins, IPA is concerned with trying to understand what it is like, from the point of view of

4 Consortia Academia Publishing (A partner of Network of Professional Researchers and Educators) 
the participants, to take their side (Smith \& Osborn, 2007).

\subsection{Research Paradigm}

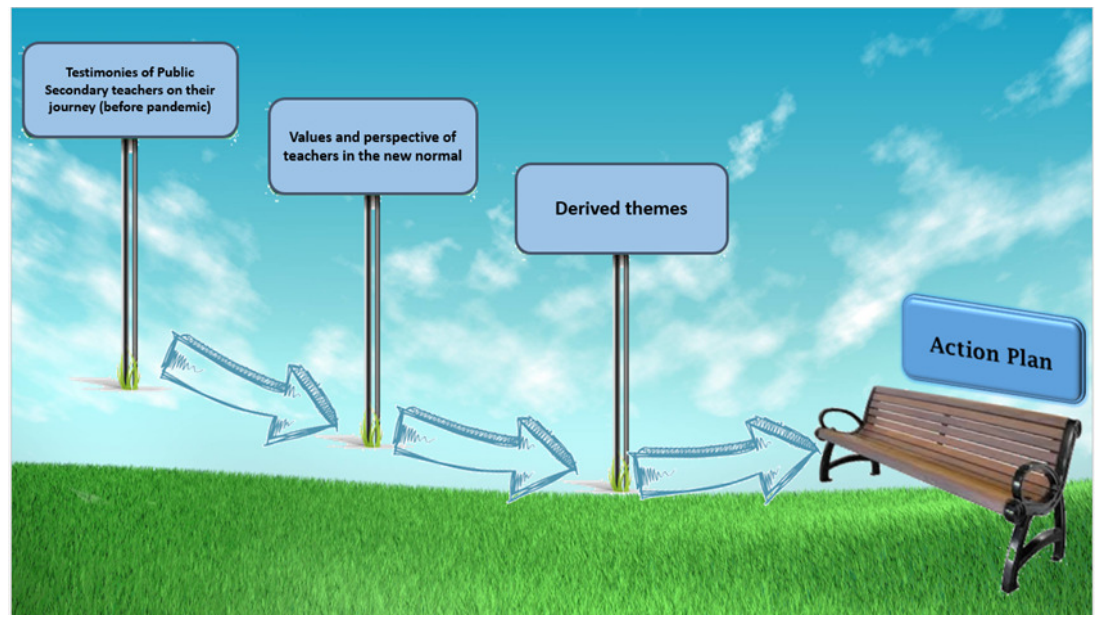

Figure 1. Research Paradigm

\subsection{Central and Corollary Questions}

The primary objective of the study was to know the day-to-day journey of public secondary teachers in the new normal, and how they coped with all the challenges they encounter in the new normal in order to ensure their values and perspectives intact. It also aimed to create a program that will help teachers in analyzing their values and perspectives amidst the challenges they faced and experienced.

What is the essence of lived experience of public secondary teachers in the new normal as to shifting of values and perspectives?

$>$ How do public secondary school teachers describe their experience as to shifting of values and perspectives in the new normal?

$>\quad$ What themes emerged from the testimonies of the public secondary school teachers to shifting of values and perspectives in the new normal?

$>\quad$ Based on the results of the study, what action plan may be proposed?

\subsection{Scope and Delimitations}

This study focused on one (1) of the 22 public secondary schools in the Division of Calamba City which is Lecheria National High School (formerly Eduardo Barretto Sr. National High School-Annex) located at Brgy. Lecheria Calamba City. This study involved 15 teachers from nine (9) departments as the participants of the study particularly looking into the essence of their lived experiences. Their views, opinions, insights, observations and emotions on their journey and challenges in the new normal, the changes in their values and perspectives and how they coped with it to be more dedicated and committed to this noble profession-teaching were taken down and analyzed.

\section{Related Literature and Studies}

Teaching and Adjusting to the New Normal - The Department of Education (DepEd) adopted the use of the Basic Education Learning Continuity Plan for the school year 2020-2021. This leaves the teachers with the responsibility of adapting to the changes brought about by the new normal in education. As teachers traverse the road of uncertainties, the choice they have affects the quality of services rendered. "Whatever is happening in the 
country; whatever challenges we are facing, education must continue. Education cannot wait; our learners cannot wait. We continue with the process so we can give hope and continuity and contribute to the normalization of activities in the country," the Secretary recounted part of the speech on the High-Level Social Development Goals Action Event on Education she presented at the United Nations in New York City on June 28, 2017. Having this in mind, teachers need to reassess themselves and have a clearer understanding of what to adopt and how to adapt. Moreover, Saxena (2020) stated that the pandemic has pushed the education sector to adopt digitization and think beyond the usual classroom teaching to provide universal access to quality education. The most obvious change has been learning shifting from the classroom to the home, with technology needing to be adopted and improved to accommodate the changes brought about by the pandemic. Teachers need to adopt various strategies to motivate students to continue learning.

In addition to, Lexia (2020) from Cambium Company published an article that emphasized that while educators continue to adjust to the change, they should remember to treat themselves with the same compassion they show to students and families. By maintaining personal connections, establishing routines, and reimagining timelines, educators can create stability and support for themselves and their students-including those who belong to the most vulnerable populations. It may not be easy to adapt to the things being done differently but surely nothing is impossible for a person that is much willing to bend for the sake of the many. Moreover, according to Dussault (2018), being a teacher is hard. Whether they are just starting or have taught for decades, teachers everywhere in the world are faced with similar challenges. The obstacles they encounter can arise from many directions: with students, parents, administrators, or with the many roles and responsibilities you must maintain.

Additionally, Manila Bulletin (2020) cited that the teachers have been finding ways to continue students' learning process, refusing to give up on their calling even amid the pandemic. There were also some articles posted in the Business Mirror (2020) that featured the perspective of two public school teachers namely Enrique Garcia from Cagayan National High School and Argy Catolin from Aglonok Primary School Iloilo. Teacher Garcia said, "Last April, when we were still under the enhanced community quarantine (ECQ), I took the initiative to come up with self-paced modules. I thought of coming up with modules because this is one way, I could help my students for the coming school year", while Teacher Catolin also stated that: "In our case in upland areas, we always give our best in helping our pupils. We did it before the pandemic through the Adopt-a-Child Program." This was supported by Olson (2020) that mentioned that in the school environment, teachers' work commitment during the COVID-19 crisis is crucial. Teachers needed to shift their methodologies coming from the set-up of having class in a physical classroom transitioning to virtual communications. Though they are groping with many obstacles brought about by the pandemic, they remain committed in the performance of their duties.

As teachers seek to prepare young people with skills for career success, Warren Buffet reminds us what makes great employees: "In looking for people to hire, look for three qualities: integrity, intelligence, and energy. And if they don't have the first one, the other two will kill you." (Mitchel, 2015). This article showed the importance of integrity not only in the teaching profession but in other fields as well. This is also one of the values that teacher would like to instill to their students. Nonetheless, despite the pandemic that is being encountered globally, teachers uphold their value of integrity. In an article written by De Vera and Noriega (2019) for Manila Bulletin, while dealing with this challenge of having students who are digital natives, Briones reminded the teachers to "observe proper online decorum and responsible netizenship" as well as to "uphold the dignity of the teaching profession." The teaching profession has always been viewed as the one who creates a greater impact to our society through the youth, it is then imperative that we uphold the highest set of values that our students may emulate. The Oxford Dictionary defined daily grind as a daily routine of work or activity, especially as considered to be dull or tiresomely repetitious; the usual day's work or routine, regarded as unremitting and laborious.

Furthermore, as the traditional face to face classes were put on hold, the education system needs to step-up

6 Consortia Academia Publishing (A partner of Network of Professional Researchers and Educators) 
and re-shape the current status of education in our country. As brought about by the pandemic, the sudden shift to distance learning has caught the Filipino people unprepared. It has also caught the teachers off guard and has to cope with the sudden change in order to deliver quality education to the Filipino people. It was never an easy task, but it entails a lot of hard work and perseverance. Ultimately, the new normal in Philippine education is characterized by remote learning that heavily relies on the students' and their respective families' capabilities to sustain quality education with minimal to almost non-existent supervision from teachers due to the fact that many families cannot afford the technology for online connectivity (Marquez, 2020).

The totality of the education system, the students, their parents and the teachers are experiencing a crisis brought about by the pandemic. Even before the pandemic, the government fell short on providing adequate educational materials to public schools, it would then be hard for them to supply all the things needed by the students and teachers for distance learning during the pandemic. In addition, even if there was some way to provide them with laptops, smartphones, or tablets, the telecommunications infrastructure of the country is ill-equipped to cater to the internet connectivity needs of everyone especially those who reside in far-flung areas (Dollanganger, 2020).

As a result, physical learning modules are the modality of choice. Unfortunately, teachers are the ones who suffer the most because they are required to reproduce these modules in spite of tight budgets (Mercado, 2020). They are also compelled to distribute these learning modules that, in some instances, may take a four-hour motorcycle ride through rocky, muddy, or uneven terrain (Casilao, 2020). This daily routine is the kind of stress that many of us were struggling nowadays because of the COVID-19 pandemic.

From an outside perspective, teaching might seem like a much less stressful job than being a nurse or physician- since they served as front liners of today. However, according to a recent poll stated in an article that was published last April 13, 2020, The Rise of Teacher Stress, 46\% of teachers report high daily stress, which ties them with nurses for the most stressful occupation in America today. As the pandemic unfolds and the days of distance learning turn to weeks, and now months, teachers face a steep learning curve every single day. The mounting stress of ensuring their students receive a quality education has translated to a handful of repeated negative emotions, according to a recent survey from the Yale Center for Emotional Intelligence and the Collaborative for Social Emotional and Academic Learning. More than 5,000 teachers responded to the survey in just three days, which asked them to describe the three most recurrent emotions they felt daily. The results indicated that teachers felt anxious, fearful, worried, overwhelmed, and sad. Anxiety was the most repeated emotion by a landslide. COVID-19 has brought a new awareness to these issues and changes need to be made in schools to prevent detrimental damage to the wellness of teachers and their students.

In addition, International Board of Credentialing and Continuing Education Standards (IBCCES) (2020) also stated that a rise in anxiety since COVID-19 is understandable considering teachers are now learning how to balance managing their own families and their needs while also working full-time and learning how to use new technology from home. Researchers chalked up the strength of these emotions to two possible causes: personal fear of safety for their families in contracting COVID-19 and taking care of their families' needs (while teaching full-time and learning the new technologies for online education).

Dussault (2018) also cited the top eight (8) classroom challenges according to teachers namely lack teamwork, empathy, and support between students, working too many roles at the same time, no time to deal with bodily functions, teachers being made accountable for more than they should, not enough time to plan, excessive paperwork for data collection, keeping up with the expectations of school's administration and applying a prescribed curriculum to all types of students. Many teachers lead a dual life while at home, just like many parents who work in other industries. Just as students need support to continue learning, teachers need support to continue teaching. Here in the Philippines, according to an official statement of Department of Education, dated May 5, 2020, preventive measures were put in place to secure the health and well-being of all personnel and for the learners as well. 
Furthermore, Ramos (2020) in her article wrote that according to Dr. Carolina Uno- Rayco that was said in a webinar broadcast by the Inquirer, educators were coping with mental disorders differently. Oftentimes they do not get to express their struggles and emotions because they are expected to always be strong, because their students and community depend on them. It was important to strengthen teacher's resiliency in dealing with "the normal stresses of life." Rayco also added that resiliency in the normal stresses of life is a characteristic of mental well-being and stated that one in five people are affected by mental disorders such as anxiety and depression. It is important to provide teachers with avenues to talk about their feelings, like setting aside time in formal meetings for "kumustahan" sessions like what some schools in Division of Calamba is doing so.

Values and Perspectives in the New Normal - According to Tadas (2019), teaching, a noble profession is a daunting and challenging task. She added that in the present era, with the advent of new methodologies in teaching and the way digital and smart learning has made inroads into the field of education, the role of teachers has also greatly evolved over a period of time. In addition to, a blog posted by Maria Barron, Cristobal Cobo, Alberto Munoz-Najar and Inaki Sanchez Ciarrusta on February 18, 2021 stated that there are two crucial factors that have shifted due to the pandemic. First, pedagogical adaptations have proven to be pivotal as the traditional lecturing in-person models do not translate to a remote learning environment. No matter the type of channel used, whether it is radio, TV, mobile, or any online platforms, teachers need to adapt their practices and be creative to keep students engaged as every household has become a classroom - more often than not - without an environment that supports learning. Second, the pandemic has recalibrated how teachers divide their time between teaching, engaging with students, and administrative tasks. In Brazil according to a survey conducted by Instituto Peninsula, $83 \%$ of teachers did not consider being prepared to teach remotely, $67 \%$ were anxious, $38 \%$ felt tired, and less than $10 \%$ were happy or satisfied. teachers are learning how adaptable and resilient educational systems, policy makers, teachers, students and families can be. That despite the overwhelming consequences of the pandemic, this global crisis has also been an extraordinary time for learning.

Moreover, Kraft (2020), an Associate Professor, co-developed a survey to help school districts better understand and respond to teachers' experience working remotely due to the coronavirus pandemic. The results of the survey suggest that the sudden shift to remote teaching has created significant challenges for teachers' work and limited the degree to which students can engage in learning. Mid-career teachers -- those most likely to have children at home -- have particularly struggled to balance their work responsibilities with their home lives during the pandemic. And seasoned teachers are over three times more likely than early-career teachers to report being uncomfortable using the technological tools required for teaching at home. The study mentioned somewhat were similar to those who were interviewed in an article written on the website of the Department of Education Division of Parañaque City. The interviewee responded:

Comment No.1 "No complain about it! It's mother's role. Besides, I am learning the technology side of it and find every day as a learning opportunity."

Comment No.2 "Making video lessons was not easy since I have to memorize everything and the recording and editing come with difficulty," and he added, "I even involve my family in the editing of my videos." But just like the famous maxim that goes "Our difficulty can be our greatest opportunity."

Comment No. 3 "This pandemic has taught me to become more prayerful and value health and life more than anything else."

Comment No. 4 "We are encouraged to practice honesty, integrity and professionalism while in the performance of service whether it be physical reporting or WFH alternative arrangement."

Similarly, Schaaf (2020) stated that educators must be facilitators of learning, not sages on stages. Despite the longstanding tradition of doing just this, the job of educators is not to stand up in front of students and show them how smart they are. Instead, an educator's job is to empower students to become independent thinkers and

8 Consortia Academia Publishing (A partner of Network of Professional Researchers and Educators) 
doers. Educators must shift the responsibility for learning from the teacher, where it has traditionally been, to their students, where it belongs. Meanwhile, Spencer (2020) Sien Tierney who said that "There are teachers who teach in the traditional way. And there are great teachers who are also model learners. They learn with the kids. They don't feel like they have to know everything, but they have to show what great learning looks like,". This reflects the changing role of teachers in the education system.

Likewise, Saxena (2020), the co-founder of InterviewBit and Scaler Academy, in one of his articles shared on the Internet stated in that because of this pandemic, the education system has drastically and has brought a paradigm shift in teaching and learning methodologies forcing educational institutions across the globe to re-imagine traditional classroom learning and transition to an online mode of teaching to provide uninterrupted access to education and knowledge. Since educational institutions were way behind in adopting technology, having focused more on classroom teaching and never having seriously considered online education as a credible model, they were slightly more unprepared than other sectors. However, due to the incredible resilience and determination, educators were quick to adapt to the new normal. Instructors and educators have had to upskill themselves almost overnight to adjust to the new modes of teaching, ensuring that learning remains accessible to students even in the current circumstances. According to Hariri and Sumintono (2020), there are four qualities of a committed teacher namely the desire to be good teachers, being more fact purveyors and sources, recognizing and accepting individual worth and meeting professional responsibilities.

Furthermore, Celik and Yildiz (2017) reiterated that commitment is the foremost need in the teaching profession. Comparably, Business Mirror on July 28, 2020, posted on the internet some experiences that teachers' eagerness to do more, beyond their work; Teacher Garcia said, "I have to consider those who have the resources and those who have limited resources. After all, I cannot utilize a one-size-fits-all scheme. I deeply understand that my students are as diverse as the dreams their hearts have known." On the other hand, Teacher Catolin also stated that "This pandemic affects everything all over the world. Until there's no vaccine we have to deal with the new normal setting. Us teachers have to be equipped with a positive attitude towards this crisis." In the same way, the answers shared by Teacher Garcia and Teacher Catolin were the same with the experiences posted on the Internet through a blog written by Heubeck (2020). To wit, "How has the shift to remote learning changed you as a teacher, for better or worse?" The following are the responses posted in the article:

Comment No. 1 "I can wholeheartedly say that the change has been, and will be, for the better. I will never again take for granted the student showing up for class early to tell me about their weekend or the student sitting in the back of the room trying to stay under the radar because they are having a bad day. These relationships are the founda-tion of the classroom and just so challenging in the remote world."

Comment No. 2 "Remote learning has served as a vehicle for me to become a more well-rounded teacher, and it has opened my eyes to the extremely difficult situations that some of our students face. It also has given me a new appreciation for the simple ability to go in to work and be with my students and colleagues."

Comment No. 3 "I think it's made me a better teacher already. I've always thought of myself as an innovator. This has really pushed the innovation envelope."

Comment No. 4 "In the long run, on the other side of this, I'll be a better teacher, and human, overall. I have more empathy for life outside of school, and I have more trust in my students and what they're capable of."

As teachers work to construct their identities, they have no choice but to pick up the discursive tools that are available to them. Therefore, many teachers define their core motivation for becoming or remaining in the profession as the capacity to make a difference in the lives of children and help individuals achieve lifelong success (Jones et al., 2020). 
Likewise, it has always been the commitment of teachers to educate the learners regardless of the situation. To contribute to the success of their students gives them a sense of accomplishment. A committed teacher is someone who is not satisfied with what she or he has, new ideas and ways are being sought to contribute to the development of their students. Today, a teacher is faced with the arduous task of keeping him/herself abreast with the latest inventions and strides in the field of medicine, education, science, art and etc. Upgrading their skills and knowledge from time to time is thus necessary and is an utmost priority today.

According to Kerr (2020), teachers are used to performing various different roles, but this year they are confronted with the most difficult tasks of their careers. They are being asked to be public health specialists. Experts in technical assistance. Social workers to families reeling from the effects of layoffs and illness. Masters of distance learning and trauma-responsive educational practices. And they are being asked to take on these new responsibilities against a backdrop of rising COVID-19 cases in many parts of the country, looming budget cuts for many school districts, and a hyper-polarized political debate over the return to school. Coping with the demands of the current education system has become an advocacy for teachers. They are trained to always make the most of every opportunity. Looking at the situation as an opportunity of change may somehow ease the burden of doing things differently. It may be quite difficult to change the pedagogical landscape that has been used before the pandemic, but teachers are resilient in coping with change.

Torres (2020), in one of her blogs said, "There is no program that could have prepared any of us to teach in a pandemic." "It's not just you." Lagua (2020) supported that to learn technology to be used in imparting knowledge to the learners nowadays is a challenge that must be accepted upfront. Today's teachers will have to embrace and master the technology that would establish connection and interaction at a different level toward a rich learning environment. Mastering meeting applications, like Zoom and Google Meet, is not simple. Add to that learning management systems, like Canvass and Moodle, that one needs to be familiar with, depending on what the institution has subscribed to. New adopters will have to face their learning curves.

Moreover, as written on one of Texas A\&M Publications (2020), "We are not all in the same boat, but we are all in the same sea. Some by yacht, some by boat and some by clinging to whatever floats our way and fighting with all of our might." Teachers are sailing in uncharted waters and so do students. In the effort of getting the most of what education could offer, the quality of teachers' work is affected. Truly, teachers in general were trained to provide knowledge and skills to their students in engaging ways this is one of so many reasons nowadays why many of them were struggling and confused at the same time.

On the other hand, Business Mirror (2020) posted on the Internet one of some responses to emphasize how teachers' unwavering commitment to deliver quality education despite the circumstances. Teacher Catolin said in the said article, "As a teacher, we have to be equipped with a positive attitude towards this crisis. Together, we can make a difference." In addition, Mr. Garcia, in that same article said that he spends his time collaborating with school leaders and his fellow teachers to create efficient class programs that will help the school adapt to the new normal. On the other hand, Lexia, a Cambium Company in one of their blogs posted that as this is an unprecedented moment in public education, it will take time and effort to adjust to the "new normal." However, by maintaining personal connections, establishing new routines, reimagining timelines, and providing additional support to vulnerable students, educators can lead the way. They may not be able to replicate classroom teaching during a pandemic, but they can certainly apply flexibility and fortitude to keep students learning in the days ahead.

Specifically, the article that was shared above are similar to the experiences of those who were interviewed in an article written by Heim (2020). The responses were as follows:

Comment No. 1 "Should I accept those limits or should I embrace the potential and leverage my creativity to create promising outcomes? I have chosen the latter."

Comment No. 2 "Yet I worried about students in successive classes touching the same books. So, 
I went on Amazon and ordered three large boxes of nitrile gloves. I've placed a pair for every student in a baggie with her or his name on it, and the baggies are stored in separate boxes in the classroom. The students enter the room, wipe down the desks I have sprayed with liquid cleaner, wash their hands with sanitizer, grab the assigned baggie, put on the gloves, grab the book on the desk, read and at the end of class put the gloves in the baggie and the baggie in the box. A terribly makeshift solution, but one that's been enthusiastically received and executed by the students. They and I each do what we need to do - that's the can-do spirit of an American."

Comment No. 3 'Exhausted. That's the best way to describe how I've felt these last four weeks. Exhausted but also kind of excited. This unfortunate circumstance has in a weird way allowed me to really try some new things."

Comment No. 4 "One of the ways I try to keep them engaged is through social media. I make TikToks about my trips and also post about them on Instagram and Twitter. I have a weekly contest where I post a video about an upcoming trip with clues. The first person to correctly guess where my next destination will be gets a prize I pick up from the gift shop and ship to them."

Comment No. 5 "My early thought process was about making this experience safe and wonderful for my students. Now that we're settling into this new way of life, I want to do everything I can not to lose this opportunity - not just for them but for myself. Keeping us all safe and healthy and learning is hard, hard work, but I'm focused and determined to give it my all. My efforts are guided by Maria Montessori's statement that "The child is both a hope and a promise for mankind."

Things may be done differently nowadays but the goal remains to be the same, that is to deliver quality education among the learners of the society. Building our resilience to the daily challenges of life is what everybody is working on. However, the threat that this pandemic has brought has not only caused teachers to be stressed with their own lives and their families, but also their deep concern about the learning and wellbeing of their students. Feeling anxious during times of crises is a natural reaction to change, especially when uncertainties cover what lies ahead.

In a research conducted by Fadli et al. (2020), they mentioned that teaching is a profession that is very dynamic in carrying out its work. Teachers are pushed to always change according to the situation, conditions and environment. This clearly describes the scenario of the education set-up at present. There are many changes that are taking place, it is the innate ability of teachers to cope with these changes that made them adapt to the fast-phased scenario of the education system. Likewise, in a research conducted by Manalo et al. (2020), the data showed that the participants' positive well-being contributes to addressing the challenges of the new normal education. Encouraging outlook, self-confidence gained from encouragement and motivation, healthy lifestyle, and stress reduction allows them to continue performing their duties and responsibilities despite the challenges of these trying times. When teachers create a positive environment and well-being among themselves, it could foster improved academic performance and promote social and emotional progress among students even outside the classroom (Loveless, 2020).

Also, Christenbury (2011) pointed out that being flexible and adaptive to changes allows teachers to survive and still succeed. Teachers are engaged in a constant desire to learn which would contribute to the growth. Flexibility and adaptability are important qualities that every teacher must acquire. Effective teachers can adjust, change, and modify teaching methodologies depending on the students' needs, availability of resources, and context of environment. They value students' achievement, rather than rigid practices.

Coping Mechanisms - A lot of people may think that teachers are doing well and having the best days of their lives because of the work-from-home setup. A lot of people were not aware that teachers had to deal with 
personal struggles at home on top of their problems at work. It is no secret that education systems here and abroad took a heavy beating from the COVID-19 pandemic. Rayner (2020) stated that stress is ever-present in the education world. To cope with stress, educators must learn to care for themselves before they can care for their students. Self-care is important for everyone, especially in times like these. While many professionals have made adjustments to their routines, perhaps none have done so more than teachers. In some cases, teachers are working remotely, juggling the demands of childcare and the classroom. He also added that working from home may offer more flexibility, but it also requires discipline in setting working hours. The constant tension between work and home can lead to feelings of guilt and frustration, leaving educators feeling as though they are never doing enough, either at work or at home. This kind of stress can lead to poor family life and poor job performance.

On the other hand, Yucarba (2020) emphasized that the pandemic has almost rewritten teachers' job descriptions. Many of them are doing more than they ever were before, and it's taking a toll on their mental health. Research shows that teacher stress and burnout might affect their students, and vice versa. To further support his ideas, the following are the responses posted in his article:

Comment No. 1 "I have never been this tired, and I had a colicky newborn! My eyes hurt, my back hurts, my hands/wrists hurt from constantly typing, I get frequent headaches that can only be minimized by taking a nap, I have mom guilt."

Comment No. 2: "The most challenging thing is having students that don't show up to sessions when I know that they need it, and they know they need it."

And while people often hear of students' and parents' struggles with online learning, teachers have their fair share of challenges as well. From preparation of lesson plans to conducting the classes and the handing out of assignments, teachers must make sure that the quality of learning remains even with the absence of face-to-face interactions. With the high levels of stress and anxiety that teachers are feeling, it is inevitable that this will end up impacting students poorly. Moreover, Rayner (2020) shared on the Internet through her blog. She gave five (5) Self-Care Tips for the Teachers: (1) Get Enough Sleep, (2) Exercise at least 30 minutes a day, (3) Eat properly, (4) Maintain social connectedness, (5) Do Good, (6) Use your sense of humor, (7) Understand that everything is temporary, and (8) Keep a sense of perspective.

In addition, Mayzenberg (2020) asserted that when it comes to a new normal in education, this means more effort from students and more patience from teachers and vice versa. People know students ultimately need to listen to their teachers, but teachers who are receptive and understanding will listen to your needs if one's still trying to give his/her best-even if one's best is a little rusty. These are all to provide a good quality kind of education. Similarly, Vezner (2020), a professor, in her article, stated that due to COVID-19, people have been thrust into a world of online learning, remote working, and socially distanced living. This shift to remote working and learning has brought some unforeseen benefits. Teachers have gained more time in our days with no commute to work or school. Teachers can integrate our work responsibilities with home responsibilities throughout the day. Teachers have increased flexibility with our personal schedules. Yet, Teachers also miss the face-to-face connections with students, colleagues, and friends, and the opportunity to teach in a physical classroom setting, engaging in face-to-face collaboration. Teachers' in-person world has become a virtual world. It is very true that change is risky and messy. What they can do is keep evaluating, questioning, and searching for ways they can adjust the teaching to meet the needs of students and families.

According to Osuba (2020), a recent survey from the American Federation of Teachers shows a majority of teachers feel stressed at work. Compared to $30 \%$ of the general population, more than $60 \%$ of teacher respondents expressed that their work is always or often stressful.

In addition, Robosa et al. (2021) pointed out that the stress teachers that go through when utilizing technology also depicts the increase in anxiety. Teachers are susceptible now that the new learning model has 
shifted to online forms. The study revealed that many teachers who are not within the "Millennial" and Gen Z timeframe are more prone to distress. "Teachers do not situate well in blended forms of learning" this is what a study on online learning states on the problems in the classes. Teachers are not trained or educated to teach virtually, so blended learning is not their normative teaching platform. This confusion causes distress and frustration across the educating community. They also stated that there is a case study on the stress state of teachers and students in Stockholm, Sweden, which revealed that any sudden change in the learning environment causes disparity and even depression across teachers. This is particularly amongst the administrative heads of educational institutions. Almost 9 of 10 teachers feel incredibly stressed and anxious, following the shift caused by the pandemic. Additionally, the survey report also revealed that $81 \%$ of the educators who were respondents of the study are putting in more than 14 hours a day to finish their professional responsibilities.

UNICEF Thailand (2020) recently published a forthcoming article discussing the adjustments teachers and students are currently undertaking given the pandemic's current situation. It was also concerned that health and education are two critical ideas that must not overlap each other. A study conducted by the University of Pennsylvania (2016) showed that stress levels might negatively affect teachers' efficacy and ability to educate students properly. Mental and emotional distractions were found to cause improper anger management and procrastination amongst teachers. According to a study-based report, teachers in the new normal would have to employ new practices and forms of management both professionally and emotionally to adapt to the virus outbreak changes fully. The report provided a structured timeline for response management, such as guidance, utilizing technology, and forming digital re-creational activities. A study surveying the impact of the virus pandemic on the general population showed that the most implicated the most affected populace are educators.

In connection to that, Canonizado (2020) stated that teachers cannot teach the lesson the way they used to teach. The majority of parents prefer written modules as an effective way of learning. Teachers' function is typically limited to planning modules, distributing and retrieving modules, answering parents' questions, and correcting learners' responses. Based on these, it is obvious that there is no contact with the learners. In the absence of a teacher, the learners study their lessons all by themselves. The new set-up may be challenging to teachers, but as usual they respond with resilience and rise above any circumstances. It is undeniably difficult to balance various tasks and responsibilities but embracing the change that has come about may lead to a better understanding of what lies ahead.

A simple way of framing stress management for teachers is by leveraging what The Mayo Clinic calls "The Four A's": Avoid, Alter, Accept, and Adapt. The first A here is Avoid which means that teachers can set themselves up for success by recognizing which stressors are simply avoidable. With a little planning and foresight, one can begin sidestepping unnecessary issues that get in the way or slow you down. Second, Alter, stress management for teachers sometimes requires creativity. Not every stressor is avoidable, so for those you cannot cross off the list, it is time to get creative. When evaluating what causes stress in teachers' job, one will likely find most problems fit neatly into this category, which fortunately means teachers can better manage their stress with slight alterations. Third, Accept, there are some pressures in life that teachers must learn to accept. It is important to focus on managing what they can control by strengthening their coping skills, remaining positive, and recognizing that frustration only further depletes your energy. And the last one is to Adapt, that will give teachers insight to adjust our standards and expectations.

According to Bruce (2018), a 2016 Harvard Business Review survey identified the ability to adapt as the most important skill for companies undergoing a digital transformation-more important than technical knowledge, communication skills or even customer-focused problem-solving. Adaptability should be in everyone's job description. In a world of constant change, non-adaptive behavior is the killer problem, he added. Accordingly, Vezner (2020), in one of his blogs, posted that the beauty of change is that it brings new possibilities. The innovation and development in online teaching has exploded. As with anything implemented in response to a significant and sudden crisis, not all online education has been excellent. Teachers need to start searching for the gems and build on those positives-what they can do is keep evaluating, questioning, and 
Rabina, L.

searching for ways they can adjust their teaching to meet the needs of our students and families.

Moreover, Jensen (2017) stated that even if people are 100 percent passionate about thier chosen employment, there are sometimes when they get stuck in the daily grind. She also added the Five (5) ways to overcome the daily grind and stay passionate about your work namely, be obsessed, take control of your time, take a break, renounce perfection, and celebrate. Stress management activities for teachers can be as simple as changing their commuting habits or as long term as practicing new classroom management techniques. They must always be reminded what Confucius said, "Choose a job you love, and you will never have to work a day in your life."

Similarly, Hendricks (2020) also wrote five (5) adjusting tips to the new normal: (1) utilize interactive platforms and games, (2) facilitate discussions and collaboration, (3) Make time for socio-emotional learning, (4) be available and flexible, and (5) prioritize your own self-care. She also added that every teacher is encouraged to find practices that will work best for their schedule, but make sure to take the time to avoid stress and burn-out. These times are difficult for parents, students, and educators alike, but everyone is all in this together and will make it through. Though sometimes teachers fear, and resists changes but still open their hearts for the opportunity to improve for the sake of their learners.

\section{Methodology}

This study utilized the qualitative research, specifically the Phenomenological Approach. According to Creswell (2014), qualitative research is an approach for exploring and understanding the meaning individuals or groups ascribe to a social or human problem. Moreover, phenomenological research is a design of inquiry coming from a philosophy and psychology in which the researcher described the lived experiences of individuals about a phenomenon as described by participants (Moustakas 1994, as cited in Giorgi, 2009). Likewise, in qualitative approach one of the key elements of collecting data in this way is to observe participants' behaviors during their engagement in activities. Researchers record information from interviews by making handwritten notes, by audiotaping, or by videotaping (Creswell, 2014). Gathered data will be summarized to analyze the phenomenon being studied.

In this study, the researcher used this design which is truly appropriate since she aimed to explore the topic as well as experiences of the participants involved in this study. She utilized the Interpretative Phenomenology Analysis (IPA) and explored in detail the individual personal and lived experiences and examined how participants were making sense of their personal and social world. Different interpretative stances were possible and IPA combined empathic hermeneutics with a questioning hermeneutics. Thus, consistent with its phenomenological origins, IPA is concerned with trying to understand what it is like, from the point of view of the participants, to take their side (Smith \& Osborn, 2007). The study was conducted to fifteen (15) public secondary teachers of Lecheria Integrated School in Calamba City from across nine (9) departments. The gathering of data became accessible to the researcher, for she herself works in the same school.

In the conduct of this qualitative research, the researcher used the purposeful random sampling. This was the most appropriate sampling for the study since this looked at a random sample and adds credibility to a sample when the potential sample is larger than one can handle. In addition to knowledge and experience, Bernard (2002) and Spradley (1979) noted the importance of availability and willingness to participate, and the ability to communicate experience and opinions in articulate, expressive, and reflective manner. The sample of the study were composed of 15 teachers from across nine (9) departments. Phenomenology is concerned with the lived experiences of the people involved with the issue or event that is being researched. The study covered the participation of 15 public teachers of Lecheria Integrated School who experienced some changes of their values and perspectives in this new normal set up of education in the Cluster 5 Division of Calamba. 
Table A

Participants of the Study

\begin{tabular}{lc}
\hline \hline \multicolumn{1}{c}{ Department/s } & No. of Participants \\
\hline \hline English & 2 \\
Science & 2 \\
Mathematics & 2 \\
Filipino & 2 \\
Araling Panlipunan & 2 \\
Edukasyon sa Pagpapakatao & 1 \\
TVL & 2 \\
MAPEH Total & 1 \\
Senior High School & 1 \\
& $\mathbf{1 5}$ \\
\hline \hline
\end{tabular}

There were two (2) participants in the English Department, two (2) in Science, another two (2) from Mathematics Department, two (2) in Filipino, two in Araling Panlipunan as well as in TVL Department. As for EsP, MAPEH and Senior High School, the researcher got one (1) respondent from each respective department. In gathering pertinent information, the researcher used ten (10) interview guide questions which were used as interview questions for teacher respondents. Thereafter, the researcher personally approached 15 public secondary teachers of Lecheria Integrated School of Cluster 5 Division of Calamba City and explained the endeavor of inquiry and purpose of the interview. The interview started in January 2021 and was completed in February 2021.

In order to ensure the validity of qualitative method used in this study and to avoid invalid conclusions such as inaccuracy or incompleteness in the way of describing what to be seen and to be heard, a cell phone was used not just to record the interview properly, but also to easily carry the instrument conveniently in the context of this study. She used the following interview questions for teachers:

1. What do you value the most in your profession?

2. How do you describe your situation as a teacher before/during pandemic?

3. What are your thoughts about the educational system?

4. What are you doing differently as a result of the new normal in education?

5. How do have you adjusted to the current situation of education in the new normal?

6. What changes have you experienced with regards to your role as a teacher in the new normal?

7. Do you think this new normal brought a shift in your values and perspective? What are these changes?

8. How does this shift affect you personally?

9. How do you think this shift in values and perspective impact the quality of your work?

10. How do you handle the impact of the shift of values and perspective brought about by the new normal?

To ensure the validity of the instrument, it was forwarded to the experts in the field including the statistician. 
Their suggestions, comments, and annotations were incorporated in the questionnaire.

The researcher personally requested a permission from the Division Superintendent with regards to the involvement of the public teachers in the research study. The purpose and objectives of the study were explained to the identified participants of the study before they had given their approval and signed for their confirmation as participants of the study. The participants were asked as to their involvement, available date, time and place. Standard health protocols in this new normal were observed in conducting face-to-face thorough interview as a data gathering tool. The interview was the integral part in the methodology of the study since it signified the meaningfulness of the experience in the perspective of the participants. With the participants' consent, the interview proper had been recorded from which summarized notes, comprehensive information, insights, feelings, encountered experiences were deduced.

The ethical guidelines as specified in the Research Manual of the school were followed by the researcher, as those ethical considerations were carefully observed throughout this paper. The interview was participated by 15 randomly selected teachers of Lecheria Integrated School. The informed consent of the participants required the researcher to explain them the importance/significance and objectives of the study. The data and information gathered were kept with confidentiality. The works of researchers of other authors were properly recognized.

For this study which was intended to look into the shift of values and perspectives in the new normal of public secondary teachers, no question that can cast insult on the capabilities of the teachers were included in the sub-questions. In addition, the sub -questions were constructed in such a way that there was no discrimination or any reference to any specific religion and organization. After gathering all the needed data from the conducted interviews, the researcher transcribed the interviews verbatim and used color-coding to take note of the responses. Afterwards, she cited relevant responses of the participants, categorized them by cluster or exemplars aligned with the interview questions utilized by the researcher and organized them in tables. She imparted her own observations of every co-researcher asked. The emerging themes were identified and extracted from the similar responses per line. Data gathered through the qualitative method were carefully summarized for a detailed narrative description.

\section{Results and Discussions}

This chapter presents the analysis and interpretation of the data gathered in this study. The intention of this phenomenological study was to consider and concentrate on the lived experiences of the public secondary teachers in Lecheria Integrated School. Their views, opinions, insights, observations and emotions on their journey and challenges in the new normal, the changes in their values and perspectives and how they coped with it to be more dedicated and committed to this noble profession-teaching-were taken down and analyzed.

As such, this research was guided by the following central question:

What is the essence of the shift of values and perspectives in the lived experiences of public secondary teachers in the new normal?

The following are the answers for the Corollary Questions:

Corollary Question 1: How do public secondary school teachers describe their experience in the shift of values and perspectives in the new normal?

Interview Question 1: What do you value the most in your profession?

Table 1 presents sample testimonies that serve as exemplars of other participants' responses. Specifically, the table provides direct quotations of respondents' concept of what they value the most in their profession. 
Table 1

Annotated Exemplars on the Teachers' Concept of What They Value the Most

\begin{tabular}{|c|c|c|}
\hline Participants & Responses & $\begin{array}{l}\text { Researcher's } \\
\text { Observation }\end{array}$ \\
\hline Teacher 1 & $\begin{array}{l}\text { "Being a teacher, ang vina-value ko masyado ay 'yung } \\
\text { commitment. Kailangan talaga ibigay 'yung best. }\end{array}$ & $\begin{array}{l}\text { Teacher } 1 \text { showed } \\
\text { seriousness in giving his } \\
\text { answer. }\end{array}$ \\
\hline
\end{tabular}

Teacher 7

"Siguro una po ay service muna. Why service? Kasi ito 'yung helping my students in the best that I could do... pagtulong sa mga bata kaya ako... gusto kong makapaglingkod kasi gusto ko magturo sa mga estudyante.
Teacher 7 exhibited a very strong conviction that teachers can make a difference in the lives of the students.

The participants of the study possessed various answers as to what they value the most in their profession but generally, they agreed that being committed in serving our students is the most important thing in their profession. Teaching has always been considered as the noble profession because teachers always put the welfare of our students above their own well-being. Likewise, the responses shared by the participants of the study were congruent to the article posted in the Business Mirror (2020) that featured the perspective of two public school teachers namely Enrique Garcia from Cagayan National High School and Argy Catolin from Aglonok Primary School Iloilo.

Teacher Garcia: "Last April, when we were still under the enhanced community quarantine (ECQ), I took the initiative to come up with self-paced modules. I thought of coming up with modules because this is one way, I could help my students for the coming school year."

Teacher Catolin: "In our case in upland areas, we always give our best in helping our pupils. We did it before the pandemic through the Adopt-a-Child Program,"

According to Hariri and Sumintono (2020), there are four qualities of a committed teacher namely the desire to be good teachers, being more fact purveyors and sources, recognizing and accepting individual worth and meeting professional responsibilities. Furthermore, Celik and Yildiz (2017) reiterated that commitment is the foremost need in the teaching profession. A committed teacher is someone who is not satisfied with what she or he has, new ideas and ways are being sought to contribute to the development of their students.

Interview Question 2: What are your thoughts about the educational system?

Table 2 reveals sample testimonies that serve as exemplars of other participants' responses. Specifically, the table provides direct quotations on teachers' thoughts about the educational system. The respondents in the study were congruent in regard to their thoughts about the educational system. These results manifested that teachers are learning how adaptable and resilient educational systems, policy makers, teachers, students and families can be. That despite the overwhelming consequences of the pandemic, this global crisis has also been an extraordinary time for learning.

Accordingly, the experiences shared by the participants of the study were the same as the study shared on the internet through a blog posted by Barron et al. (2021). They stated that there are two crucial factors that have shifted due to the pandemic. First, pedagogical adaptations have proven to be pivotal as the traditional lecturing in-person models do not translate to a remote learning environment. No matter the type of channel used (radio, 
Rabina, L.

$\mathrm{TV}$, mobile, online platforms, etc.) teachers need to adapt their practices and be creative to keep students engaged as every household has become a classroom - more often than not - without an environment that supports learning. Second, the pandemic has recalibrated how teachers divide their time between teaching, engaging with students, and administrative tasks. In Brazil according to a survey conducted by Instituto Peninsula, $83 \%$ of teachers did not consider being prepared to teach remotely, $67 \%$ were anxious, $38 \%$ felt tired, and less than $10 \%$ were happy or satisfied.

Table 2

Annotated Exemplars on the Teachers' Thoughts about Educational System

\begin{tabular}{|c|c|c|}
\hline Participants & Responses & $\begin{array}{l}\text { Researcher's } \\
\text { Observation }\end{array}$ \\
\hline Teacher 2 & $\begin{array}{l}\text { "Marami pa tayong dapat gawin sa educational system kasi parang } \\
\text { walang consistency, kasi sa mga decision wala 'yung sa totoo lang, } \\
\text { parang ang dami daming gustong ipaturo sa bata, sa sobrang dami, 'yung } \\
\text { curriculum overloaded na sa mga topics na parang wala ng naiintindihan } \\
\text { ang mga bata." }\end{array}$ & $\begin{array}{l}\text { It was observed that } \\
\text { Teacher } 2 \text { was a little } \\
\text { bit sad while stating } \\
\text { her answer. }\end{array}$ \\
\hline Teacher 7 & $\begin{array}{l}\text { "Naku, heto parang kulang sa sistema but in fairness naman...ginagawa } \\
\text { naman nila ang best nila para magtuloy-tuloy ang ang edukasyon ng mga } \\
\text { bata... May kulang sa sistema o sabihin na nating minadali. Sa } \\
\text { paghahanda na lang mg module...Iba-iba ang ginagawa ng bawat } \\
\text { region... hindi kasi tayo handa. Sila ang nagpaplano, tayo ang } \\
\text { gumagawa...'di nila alam nahihirapan din ang mga teacher."." }\end{array}$ & $\begin{array}{l}\text { Teacher } 7 \text { was serious } \\
\text { while stating her } \\
\text { answer. }\end{array}$ \\
\hline
\end{tabular}

Interview Question 3: What changes have you experienced with regards to your role as a teacher in the new normal?

Table 3 presents sample testimonies that serve as exemplars of other participants' responses. Specifically, the table provides direct quotations on teachers' changing role in the new normal.

Table 3

Annotated Exemplars on the Changing Role of Teachers in the New Normal

\begin{tabular}{|c|c|c|}
\hline Participants & Responses & $\begin{array}{l}\text { Researcher's } \\
\text { Observation }\end{array}$ \\
\hline Teacher 2 & $\begin{array}{l}\text { "Parang ngayon ang role ko na lang talaga ay magbigay ng } \\
\text { instructions...'di na ikaw ang nagtuturo...Nagbibigay na lang ng } \\
\text { supplementary lessons, videos... Ang ibibigay ko ay 'yung gabay } \\
\text { sa kung ano ang dapat nilang gawin." }\end{array}$ & $\begin{array}{l}\text { Teacher } 2 \text { has sadness } \\
\text { in her voice while } \\
\text { answering. }\end{array}$ \\
\hline Teacher 14 & $\begin{array}{l}\text { "Teachers play many important roles... As of today, the number } \\
\text { of roles we play were reduced to Module and Activity Sheets } \\
\text { Creator, Subject Consultants, Class Monitors and Output } \\
\text { Checkers and Recorders. They may be few but all those are quite } \\
\text { difficult and laborious play an important role in student } \\
\text { development." }\end{array}$ & $\begin{array}{l}\text { Teacher } 14 \text { uttered hes } \\
\text { answer with a } \\
\text { disappointing } \\
\text { expression and tone of } \\
\text { voice. }\end{array}$ \\
\hline
\end{tabular}

The participants of the study uttered various responses with regards to their experiences on their role as a teacher in the new normal. Still, the common good and what is best for the learners were the priorities of the 
teachers in order to ensure still a quality education in spite of this crisis people are facing until today. Likewise, the experiences shared by the respondents of the study were the same as the experiences shared on the internet through an article posted by Saxena (2020), the co-founder at InterviewBit and Scaler Academy. He stated in his article that because of this pandemic, the education system has drastically and has brought a paradigm shift in teaching and learning methodologies forcing educational institutions across the globe to re-imagine traditional classroom learning and transition to an online mode of teaching to provide uninterrupted access to education and knowledge. Since educational institutions were way behind in adopting technology, having focused more on classroom teaching and never having seriously considered online education as a credible model, they were slightly more unprepared than other sectors. However, due to the incredible resilience and determination, educators were quick to adapt to the new normal. Instructors and educators have had to upskill themselves almost overnight to adjust to the new modes of teaching, ensuring that learning remains accessible to students even in the current circumstances.

In addition, Ryan Schaaf in his article on September 16, 2020 stated that educators must be facilitators of learning, not sages on stages. Despite the longstanding tradition of doing just this, the job of educators is not to stand up in front of students and show them how smart they are. Instead, an educator's job is to empower students to become independent thinkers and doers. Educators must shift the responsibility for learning from the teacher, where it has traditionally been, to their students, where it belongs.

Interview Question 4: Do you think this new normal brought a shift in your values and perspectives? What are these changes?

Table 4 presents sample testimonies that serve as exemplars of other participants' responses. Specifically, the table provides direct quotations on respondents' shift of values and perspectives in the new normal.

\section{Table 4}

Annotated Exemplars on the Shift of Values and Perspectives in the New Normal

\begin{tabular}{|c|c|c|}
\hline Participants & Responses & $\begin{array}{l}\text { Researcher's } \\
\text { Observation }\end{array}$ \\
\hline Teacher 1 & $\begin{array}{l}\text { "Yes, maraming pagbabago sa values ang perspectives. Una nga, } \\
\text { pagdating sa mga values maraming mga values ang na develop } \\
\text { sa akin ngayon, unang-una yung patience, 'yung pagiging } \\
\text { considerate, tapos 'yung concern, mercy, compassion sa mga } \\
\text { bata. Pagdating naman sa perspectives, nabago sa akin nito, mas } \\
\text { nalilikot ko ang isip ko to suggest something kasi kumbaga kung } \\
\text { hindi tayo mag-e-explore ng mga bagay-bagay, ng mga } \\
\text { strategies, hindi tayo mag-i-improve sa school... 'yung pagiging } \\
\text { risk taker." }\end{array}$ & $\begin{array}{l}\text { Teacher } 1 \text { maintain } \\
\text { an eye contact wh } \\
\text { proudly delivering } 1 \\
\text { answer. }\end{array}$ \\
\hline Teacher 12 & $\begin{array}{l}\text { "Yes, it does. This pandemic taught me how to be more } \\
\text { understanding, be more considerate, and be thankful. If it's hard } \\
\text { for me to cope up with my daily routines, I bet it's even harder to } \\
\text { other people... Everybody struggles, we just need some } \\
\text { adjustments so we can understand each other." }\end{array}$ & $\begin{array}{l}\text { With her enthusiast } \\
\text { tone of voice, Teach } \\
12 \text { delivered her answ } \\
\text { positively. }\end{array}$ \\
\hline
\end{tabular}

The participants in the study were united in their responses regarding the shift of values and perspectives brought in the new normal. These results manifested that teachers are human too. Though sometimes they fear and resist changes, teachers still open their hearts for the opportunity to improve for the sake of their learners. Similarly, the experiences shared by the respondents of the study were the same to the article posted by Vezner (2020). She stated that due to COVID-19, people have been thrust into a world of online learning, remote working, and socially distanced living. This shift to remote working and learning has brought some unforeseen 
Rabina, L.

benefits. People have gained more time every day with no commute to work or school. People can integrate work responsibilities with home responsibilities throughout the day. People have increased flexibility with personal schedules. Yet, people also miss the face-to-face connections with students, colleagues, and friends, and the opportunity to teach in a physical classroom setting, engaging in face-to-face collaboration.

People's in-person world has become a virtual world. It is very true that change is risky and messy. What everyone can do is keep evaluating, questioning, and searching for ways that can adjust the teaching to meet the needs of students and families. According to Hendricks (2020), there are five (5) adjusting tips to the new normal: (1) utilize interactive platforms and games, (2) facilitate discussions and collaboration, (3) make time for socio-emotional learning, (4) be available and flexible, and (5) prioritize self-care. She also added that every teacher is encouraged to find practices that will work best for their schedule, but make sure to take the time to avoid stress and burn-out. Just remember, these times are difficult for parents, students, and educators alike, but we are all in this together and will make it through.

Interview Question 5: How do you think this shift in values and perspective impacts the quality of your work?

Table 5 presents sample testimonies that serve as exemplars of other participants' responses. Specifically, the table provides direct quotations on the impact of the shift of values and perspectives to the teachers' quality of work.

Table 5

Annotated Exemplars on the Impact of the Shift of Values and Perspectives to the Teacher's Quality of Work

\begin{tabular}{|c|c|c|}
\hline Participants & Responses & $\begin{array}{l}\text { Researcher's } \\
\text { Observation }\end{array}$ \\
\hline Teacher 12 & $\begin{array}{l}\text { "These changes provided me an opportunity to be a better } \\
\text { public servant. Being empathic among others...and when } \\
\text { you are kind, understanding and considerate, you will be } \\
\text { loved by many. It's fun to work, to dream, and to set goals } \\
\text { when everyone around you loves you and supports you." }\end{array}$ & $\begin{array}{l}\text { Teacher } 12 \text { uttered } \mathrm{h} \\
\text { answer with a pleasa } \\
\text { facial expression. }\end{array}$ \\
\hline Teacher 13 & $\begin{array}{l}\text { "I realized that I have to work well and do all the best that } \\
\text { I can, because I am grateful that despite this pandemic, I } \\
\text { still have job... something to offer to my family and despite } \\
\text { the struggle, I should never give up. Everything will come } \\
\text { to an end and a brighter days will come." }\end{array}$ & $\begin{array}{l}\text { Teacher } 13 \text { delivered } h \\
\text { answer with a smile on } h \\
\text { face. }\end{array}$ \\
\hline
\end{tabular}

The participants of the study have various answers as to what they think will be the impact of this shift of values and perspectives in the quality of their work but though they have different answers it still points to one goal, that they are open and willing to adapt changes in order to maintain the quality of their work especially to their learners. According to Bruce (2018), a 2016 Harvard Business Review survey identified the ability to adapt as the most important skill for companies undergoing a digital transformation-more important than technical knowledge, communication skills or even customer-focused problem-solving. Adaptability should be in everyone's job description. In a world of constant change, non-adaptive behavior is the killer problem, he added.

In addition, Vezner (2020) in one of his blogs posted that the beauty of change is that it brings new possibilities. The innovation and development in online teaching has exploded. As with anything implemented in response to a significant and sudden crisis, not all online education has been excellent. One needs to start searching for the gems and build on those positives. What people can do is keep evaluating, questioning, and 
searching for ways they can adjust the teaching to meet the needs of the students and families.

Interview Question 6: How do you describe your situation as a teacher before/during pandemic?

Table 6 presents sample testimonies that serve as exemplars of other participants' responses. Specifically, the table provides direct quotations about teachers' situation before/during pandemic.

Table 6

Annotated Exemplars on the Situation of Teachers' Before / During Pandemic

\begin{tabular}{|c|c|c|}
\hline Participants & Responses & $\begin{array}{l}\text { Researcher's } \\
\text { Observation }\end{array}$ \\
\hline Teacher 2 & $\begin{array}{l}\text { "Mahirap talaga ngayon sa lahat ng bagay, sa lahat ng aspeto } \\
\text { kesa noong wala pang pandemic. Kahit nai-stress ka sa bata } \\
\text { noon, 'yung mental health 'di ganun ka-problema. Lalo na } \\
\text { ngayon kailangan mong sagutin ang bata sa sangkaterbang chat } \\
\text { at GC araw-araw. Hindi mo na ma-identify 'yung oras ng } \\
\text { trabaho mo pag nasa bahay..." }\end{array}$ & $\begin{array}{l}\text { Teacher } 2 \text { responded } \\
\text { the question with a fit } \\
\text { tone of voice and serio } \\
\text { facial expression. }\end{array}$ \\
\hline Teacher 14 & $\begin{array}{l}\text { “...teaching during the pandemic for me is equally challenging } \\
\text { as it was before. Especially in terms of communicating with } \\
\text { students since some of them do not have the means. I feel bad } \\
\text { that I can do more for my students than just checking and } \\
\text { recording their outputs, but I can't give my } 100 \% \text { to them since } \\
\text { all of us are very limited in a lot of aspects. As much as I love } \\
\text { being at the comfort and having the perks of working from my } \\
\text { own home, I would really prefer going to school and have face } \\
\text { to face classes for the sake of the students.” }\end{array}$ & $\begin{array}{l}\text { Teacher } 14 \text { maintain } \\
\text { an eye contact as } \\
\text { answered the question }\end{array}$ \\
\hline
\end{tabular}

The participants in the study were mostly the same in their responses with regard to their situation as a teacher before/during pandemic. These results served as a basis to emphasize teachers' difficulties in delivering and imparting knowledge to their learners especially during this time and at the same time their eagerness to do more, beyond their work, since it is their profession as a teacher. Comparably, the experiences shared by the respondents of the study were the same to the experiences posted on the Internet through a Business Mirror (2020).

Teacher Garcia: "I have to consider those who have the resources and those who have limited resources. After all, I cannot utilize a one-size-fits-all scheme. I deeply understand that my students are as diverse as the dreams their hearts have known."

Teacher Catolin: "This pandemic affects everything all over the world. Until there's no vaccine we have to deal with the new normal setting. Us teachers have to be equipped with a positive attitude towards this crisis."

Interview Question 7: What are you doing differently as a result of the new normal in education?

Table 7 presents sample testimonies that serve as exemplars of other participants' responses. Specifically, the table provides direct quotations on the teachers' new normal in education. The participants in the study were unanimous in their responses with regards to what they have done differently as a result of the new normal in education. These results served as a basis to emphasize the use of technologies and different educational platforms in helping the learners to understand the learnings that the teachers want to impart.

Comparably, the experiences shared by the participants of the study were the same to the article posted in the internet through a blog of Edutopia posted by Lagua (2020). He stated that to learn technology to be used in 
Rabina, L.

imparting knowledge to the learners nowadays is a challenge that must be accepted upfront. Today's teachers will have to embrace and master the technology that would establish connection and interaction at a different level toward a rich learning environment. Mastering meeting applications, like Zoom and Google Meet, is not simple. Add to that learning management systems, like Canvass and Moodle, that one needs to be familiar with, depending on what the institution has subscribed to. New adopters will have to face their learning curves.

Table 7

Annotated Exemplars on the Teachers' New Normal in Education

\begin{tabular}{|c|c|c|}
\hline Participants & Responses & $\begin{array}{l}\text { Researcher's } \\
\text { Observation }\end{array}$ \\
\hline Teacher 13 & $\begin{array}{l}\text { "...I patiently call and explain the lessons to the students who } \\
\text { cannot deal with my subject... a one-on-one talk via messenger } \\
\text { or cellular phone so that the lesson will be clearly understood. } \\
\text { For those students whose level of understanding is below basic } \\
\text { or basis, I must design activity sheets that will fit to them and } \\
\text { their understanding." }\end{array}$ & $\begin{array}{l}\text { Teacher } 13 \text { show } \\
\text { animated expression a] } \\
\text { proudly stated h } \\
\text { answer. }\end{array}$ \\
\hline Teacher 5 & $\begin{array}{l}\text { "Napakalaki ng pagbabago. “yung una dapat nga mahaba ang } \\
\text { pasensya mo kasi kailangan mag-e-exert ka ng pasensya sa mga } \\
\text { bata. Hindi mo agad pwedeng pagalitan ang mga bata. } \\
\text { Pangalawa, 'yung technology, dapat magaling ka talaga. } \\
\text { Another, 'yung pagche-check natin online, 'yung health natin, } \\
\text { majority nasa harap tayo ng computer/laptop, yung radiation. } \\
\text { Lagi kang nakaharap sa cp. Napakadaming GC ngayon. } \\
\text { Napakadaming meetings... ang mga bata dapat monitor lagi. } \\
\begin{array}{l}\text { Dapat flexible tayo... marunong tayong humarap sa mga } \\
\text { pagbabago }\end{array}\end{array}$ & $\begin{array}{l}\text { With a serious tone } \\
\text { voice, Teacher } 5 \text { sligh } 1 \\
\text { nodded her head af } \\
\text { giving the answer. }\end{array}$ \\
\hline
\end{tabular}

Interview Question 8: How have you adjusted to the current situation of education in the new normal?

Table 8 illustrates sample testimonies that serve as exemplars of other participants' responses. Specifically, the table provides direct quotations on the teachers' adjustments in the new normal. The participants in the study were unanimous in their responses with regard to their adjustment to the current situation of education in the new normal. These results served as a basis to emphasize how teachers' unwavering commitment to deliver quality education despite the circumstances. Likewise, the experiences shared by the respondents of the study were the same to the experiences posted on the internet through a Business Mirror (2020).

Teacher Catolin: "As a teacher, we have to be equipped with a positive attitude towards this crisis. Together, we can make a difference."

In addition, Mr. Garcia, in that same article said that he spends his time collaborating with school leaders and his fellow teachers to create efficient class programs that will help the school adapt to the new normal. On the other hand, Lexia, a Cambium Company in one of their blogs posted that as this is an unprecedented moment in public education, it will take time and effort to adjust to the "new normal." However, by maintaining personal connections, establishing new routines, reimagining timelines, and providing additional support to vulnerable students, educators can lead the way. They may not be able to replicate classroom teaching during a pandemic, but they can certainly apply flexibility and fortitude to keep students learning in the days ahead. 
Table 8

Annotated Exemplars on the Teachers' Adjustments in the New Normal

\begin{tabular}{|c|c|c|}
\hline Participants & Responses & $\begin{array}{l}\text { Researcher's } \\
\text { Observation }\end{array}$ \\
\hline Teacher 10 & $\begin{array}{l}\text { "Many adjustment I have to take po kasi just to give po, proper } \\
\text { guidance po, kasi po sa learners natin it takes a lot of } \\
\text { adjustment po since ang ginagawa ko po is that I go with the } \\
\text { flow... have a proper time management and I think I have to } \\
\text { have an open mind po to be able to learn more yung mga } \\
\text { platforms, different platforms po." }\end{array}$ & $\begin{array}{l}\text { Teacher } 10 \text { uttered } 1 \\
\text { answers with convicti } \\
\text { that was evident with } h \\
\text { voice and fac: } \\
\text { expression. }\end{array}$ \\
\hline Teacher 8 & $\begin{array}{l}\text { "Nag-a-adjust pa rin po, kasi iba-iba naman po e. Kumbaga } \\
\text { hindi naman natin masasabing nakapag-adjust na kasi araw- } \\
\text { araw iba naman po ang mga gawain natin na ginagawa. } \\
\text { Syempre may mga pag-iisip pa rin po tayo na syempre hindi } \\
\text { naman natin para magpanggap na 'di tayo nahihirapan. } \\
\text { Darating na darating po talaga 'yun sa punto na mahihirapan } \\
\text { tayo kasi parang hindi natin naiisip, kahit ako minsan, naiisip } \\
\text { ko parang 'di natatapos 'yung trabaho." }\end{array}$ & $\begin{array}{l}\text { Teacher } 8 \text { answered wi } \\
\text { a smile on her face. }\end{array}$ \\
\hline
\end{tabular}

Interview Question 9: How does this shift affect you personally?

Table 9 shows sample testimonies that serve as exemplars of other participants' responses. Specifically, the table provides direct quotations on the effect of the shift of values and perspectives in the new normal on teachers.

Table 9

Annotated Exemplars on the Effect of the Shift of Values and Perspectives in the New Normal

\begin{tabular}{|c|c|c|}
\hline Participants & Responses & $\begin{array}{l}\text { Researcher's } \\
\text { Observation }\end{array}$ \\
\hline Teacher 1 & $\begin{array}{l}\text { "Naka-stress. Maraming distractions. Mas maganda mag- } \\
\text { trabaho sa labas... sa mismong workplace. Kasi 'pag nandito } \\
\text { ka sa bahay, mahirap i-feel na nagtatrabaho ka, kasi nahahati } \\
\text { ang oras mo. "yung productivity level... Siguro factor na na rin } \\
\text { ang pandemic, kasi nandito lang tayo sa loob ng bahay. Kasi } \\
\text { kung nakakalabas tayo, maba-balance." }\end{array}$ & $\begin{array}{l}\text { Teacher } 1 \text { has sadness } \\
\text { in his voice while } \\
\text { stating his answer. }\end{array}$ \\
\hline Teacher 11 & $\begin{array}{l}\text { "Really affect my personality, Stress triggers, in doing task that } \\
\text { sometimes it is impossible to happen since it is directed to you } \\
\text { well no choice..." }\end{array}$ & $\begin{array}{l}\text { With her unhappy eye } \\
\text { and voice, Teacher } 11 \\
\text { responded to the } \\
\text { question asked } \\
\text { seriously. }\end{array}$ \\
\hline
\end{tabular}

The participants in the study were almost the same in their responses with regards to the effect of the shift of values and perspectives in the new normal. These results showed that teachers are human too, that they need also to take care of themselves in order to continue serving their learners, though it will take a while to get used to this kind of situation. Rayner (2020) asserted that stress is ever-present in the education world. To cope with 
stress, educators must learn to care for themselves before they can care for their students. Self-care is important for everyone, especially in times like these. While many professionals have made adjustments to their routines, perhaps none have done so more than teachers. In some cases, teachers are working remotely, juggling the demands of childcare and the classroom. He also added that working from home may offer more flexibility, but it also requires discipline in setting working hours. The constant tension between work and home can lead to feelings of guilt and frustration, leaving educators feeling as though they are never doing enough, either at work or at home. This kind of stress can lead to poor family life and poor job performance.

On the other hand, Yucarba (2020) emphasized that the pandemic has almost rewritten teachers' job descriptions. Many of them are doing more than they ever were before, and it is taking a toll on their mental health. Research shows that teacher stress and burnout might affect their students, and vice versa. To further support his ideas, the following are the responses posted in his article:

Comment No. 1 "I have never been this tired, and I had a colicky newborn! My eyes hurt, my back hurts, my hands/wrists hurt from constantly typing, I get frequent headaches that can only be minimized by taking a nap, I have mom guilt."

Comment No. 2: "The most challenging thing is having students that don't show up to sessions when I know that they need it, and they know they need it."

Interview Question 10: How do you handle the impact of the shift of values and perspective brought about by the new normal?

Table 10 illustrates sample testimonies that serve as exemplars of other participants' responses. Specifically, the table provides direct quotations on the teachers' way of handling the shift of values and perspective in the new normal.

Table 10

Annotated Exemplars on the Teachers' Way of Handling the Shift of Values and Perspective in the New Normal

\begin{tabular}{|c|c|c|}
\hline Participants & Responses & $\begin{array}{l}\text { Researcher's } \\
\text { Observation }\end{array}$ \\
\hline Teacher 5 & $\begin{array}{l}\text { "Willingness to adjust and willingness to learn, 'yun lang sa } \\
\text { tingin ko ang key para maging successful tayo, kasi lahat ng } \\
\text { bagay nagbabago... Oo sa una mahirap talaga e, pero 'pag } \\
\text { nandyan 'yung willingness natin matuto... mag-adjust, hindi } \\
\text { naman perpekto pero makukuha din natin 'yan lalo't araw- } \\
\text { araw na ginagawa. Mahalin natin ang ating trabaho. Positive } \\
\text { lang..." }\end{array}$ & $\begin{array}{l}\text { With a convinci } \\
\text { voice, Teacher } \\
\text { delivered his answ } \\
\text { smilingly. }\end{array}$ \\
\hline Teacher 1 & $\begin{array}{l}\text { Mas ini-improve ko pa, mas inaapply ko pa sa mga bata sa } \\
\text { pagsagot ng mga queries, 'yung mga kailangan nila. Masyado } \\
\text { ako ma-explore. Ini-explore ko pa kung ano pa ang dapat kong } \\
\text { matutunan. Sinu-sustain ko 'yung mga bago kong learnings kasi } \\
\text { hindi ako sanay na walang ginagawa. 'Yung mga bagay, mga } \\
\text { strategies na dapat kong i-suggest, mas pinag-aaralan ko pa. } \\
\text { Self-study... Hindi ako natatakot magtanong sa ibang school. } \\
\text { Hindi ko sinasarili...pinag-aaralan ko ang mga proseso }\end{array}$ & $\begin{array}{l}\text { Teacher 1, with } \\
\text { serious tone, express } \\
\text { his answer proudly. }\end{array}$ \\
\hline
\end{tabular}

The participants in the study were optimistic in their responses with regards to their ways in dealing with the impact of the shift of values and perspectives brought about by the new normal about the educational system. These results showed that making the well-being of teachers a priority and to provide them with the proper programs and resources they need to be successful to create healthier classroom environments for both the teachers and students. More so, the experiences shared by the participants of the study were the same as the 
study shared on the internet through a blog posted by Rayner (2020). Teaching in the age of COVID-19 is stressful, but by caring for ourselves, we can better care for our students. Nothing is more important than that. She gave Five (5) Self-Care Tips for the Teachers, (1) Get Enough Sleep, (2) Exercise at least 30 minutes a day, (3) Eat properly, (4) Maintain social connectedness, (5) Do Good, (6) Use your sense of humor, (7) Understand that everything is temporary, and (8) Keep a sense of perspective.

In addition, Mayzenberg (2020) stated that when it comes to a new normal in education, this means more effort from students and more patience from teachers and vice versa. It is said that students ultimately need to listen to their teachers, but teachers who are receptive and understanding will listen to one's needs if one is still trying to give his/her best- - even if his/her best is a little rusty. These are all to provide a good quality kind of education.

Corollary Question 3: What themes emerged from the lived experiences of public secondary school teachers?

The following themes emerged based on the qualitative data analysis performed: for the first corollary question these are Core Values of Teachers, the Education System in Crisis, Paradigm Shift in Teaching, Positive Change and Quality of Work During the Pandemic. For the second corollary question, these are Comparing Then and Now, coping with the New Normal in Education, Adopt and Adapt in the New Normal, Work Life Balance and above all, Resilience. Figure 2. Provides visual representation of the themes:
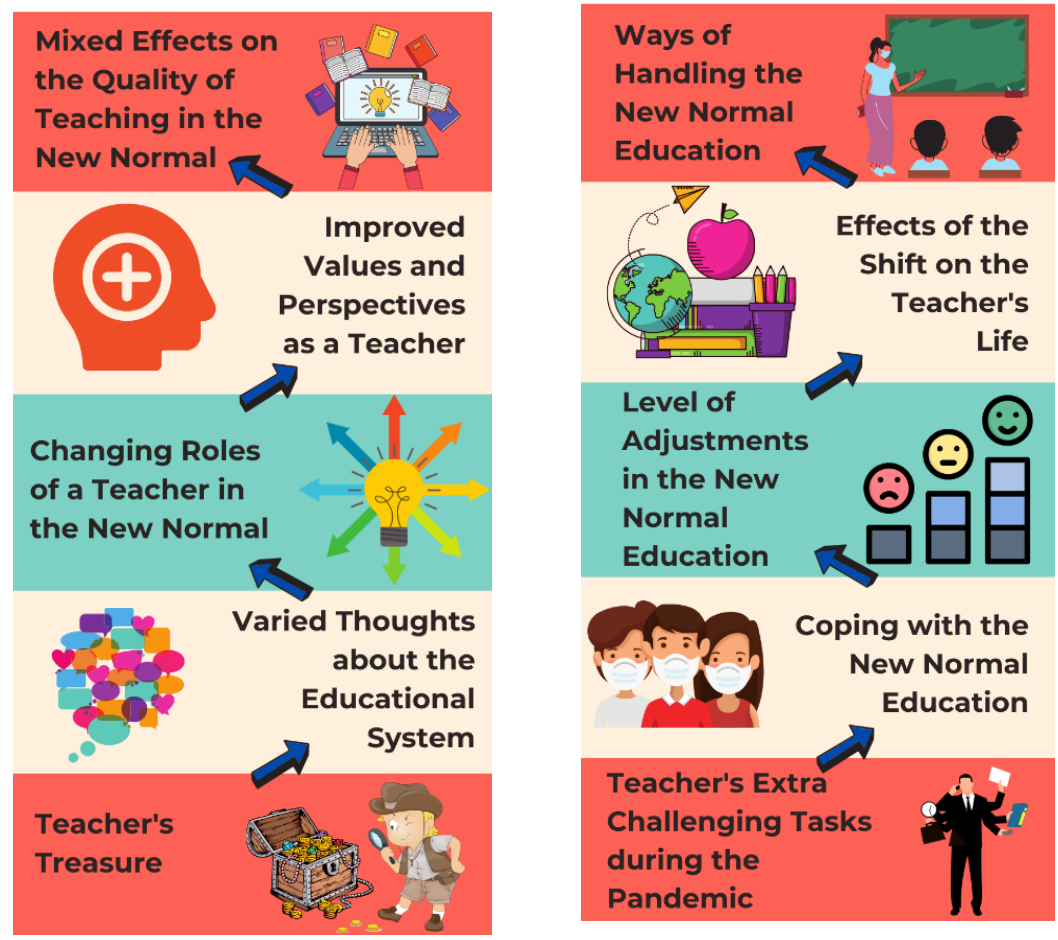

Figure 2. Emerging Themes

Interview Question 1: What do you value the most in your profession?

The participants shared their own views on what they value most in their profession. They expressed their opinions in various ways but it boiled down to three core values. These are commitment, integrity and dignity. They mentioned that teaching is a noble profession and that being of service to their students is the most valuable thing that they have as a teacher. They are committed to give their utmost service to the students because they believe that the student's achievement is their achievement too. They also value integrity and dignity. They see to it that they walk the talk. 
Thematic Chart A

Teacher's Treasure

\begin{tabular}{|c|c|c|}
\hline Participants & Responses & $\begin{array}{c}\text { Subordinat } \\
\text { Themes }\end{array}$ \\
\hline Teacher 3 & $\begin{array}{l}\text { "Siguro po "yung pagmamahal ng estudyante sa kanyang guro, yun di } \\
\text { matatawaran." }\end{array}$ & Students \\
\hline Teacher 4 & $\begin{array}{l}\text { "Mga students, kasi 'yung students ang pinaka-main or nagsa-satisfy ng } \\
\text { ating profession..." }\end{array}$ & \\
\hline Teac & “...my students' achievement is my achievement too." & \\
\hline Tea & $\begin{array}{l}\text { "...I value the most are my students. They are the heart and center of the } \\
\text { teaching and learning process. In everything we do, we always take them } \\
\text { into consideration." }\end{array}$ & \\
\hline Teacher 1 & $\begin{array}{l}\text { "Being a teacher, ang vina-value ko masyado ay 'yong commitment. } \\
\text { Kailangan talaga ibigay 'yung best." }\end{array}$ & Commitmer \\
\hline Teacher 6 & $\begin{array}{l}\text { "I think 'yong vina-value ko dito as ateacher, siguro 'yong commitment } \\
\text { natin sa mga bata. }\end{array}$ & \\
\hline Teacher 7 & $\begin{array}{l}\text { "Siguro una po ay service muna. Why service? Kasi ito 'yung helping my } \\
\text { students in the best that I could do..." }\end{array}$ & $\begin{array}{l}\text { Helping my } \\
\text { Students }\end{array}$ \\
\hline Teacher 12 & $\begin{array}{l}\text { "I value my students the most. I always see to it that they learned from me } \\
\text { at the end of the day." }\end{array}$ & $\begin{array}{l}\text { Valuing my } \\
\text { Students }\end{array}$ \\
\hline Teac & $\begin{array}{l}\text { "I valued most in my profession is to fulfill my duties and responsibilities. } \\
\text { Performed it with commitment and dedication with integrity." }\end{array}$ & $\begin{array}{l}\text { Commitmer } \\
\text { and } \\
\text { Dedication }\end{array}$ \\
\hline Teacher 15 & $\begin{array}{l}\text { "The most important part of teaching is having dedication. We are not here } \\
\text { or we are not teaching for recognition or paycheck but because we/I have a } \\
\text { passion for youth and education." }\end{array}$ & Dedication \\
\hline Teacher 8 & $\begin{array}{l}\text { "Tayo po bilang mga guro mahalaga po na pangalagaan natin ang } \\
\text { integridad natin bilang guro at pagiging tao natin." }\end{array}$ & Integrity \\
\hline Teacher 9 & $\begin{array}{l}\text { "As a teacher, ever since I become a teacher what I value the most is my } \\
\text { manner, respect and dignity". }\end{array}$ & $\begin{array}{l}\text { Respect an } \\
\text { Dignity }\end{array}$ \\
\hline Tea & "So I think as a teacher what I value most is our dignity po." & Dignity \\
\hline Teacher 5 & $\begin{array}{l}\text { "Syempre sa profession natin ang vina-value natin dito ay 'yong work natin } \\
\text { as a teacher, noble profession." }\end{array}$ & $\begin{array}{l}\text { Profession' } \\
\text { Nobility }\end{array}$ \\
\hline Teacher 2 & $\begin{array}{l}\text { "Syempre "yung relationship ko with my co-workers kasi ang mga bata } \\
\text { andun na naman lagi yan, hindi naman tayo mawawalan ng estudyante." }\end{array}$ & $\begin{array}{l}\text { Relationshi] } \\
\text { with } \\
\text { Colleagues }\end{array}$ \\
\hline
\end{tabular}

In the school environment, teachers' work commitment during the COVID-19 crisis is crucial. Teachers needed to shift their methodologies coming from the set-up of having class in a physical classroom transitioning to virtual communications. Though they are groping with many obstacles brought about by the pandemic, they remain committed in the performance of their duties (Olson, 2020). As people seek to prepare young people with skills for career success, Warren Buffet reminded people what makes great employees and that is when looking for people to hire, it is important to look for three qualities which are integrity, intelligence, and energy. And if they do not have the first one, the other two will kill you (Mitchel, 2015). This article showed the importance of integrity not only in the teaching profession but in other fields as well. This is also one of the values that teacher would like to instill to their students. Despite the pandemic that is being encountered globally, teachers uphold their value of integrity.

In an article written by De Vera and Noriega for Manila Bulletin (2019), while dealing with this challenge of having students who are digital natives, Briones reminded the teachers to "observe proper online decorum and responsible netizenship" as well as to "uphold the dignity of the teaching profession." The teaching profession has always been viewed as the one who creates a greater impact to our society through the youth, it is then imperative that we uphold the highest set of values that our students may emulate.

Interview Question 2: What are your thoughts about the educational system?

As the traditional face to face classes were put on hold, the education system needs to step-up and re-shape the current status of education in our country. As brought about by the pandemic, the sudden shift to distance learning has caught the Filipino people unprepared. It has also caught the teachers off guard and has to cope with 
the sudden change in order to deliver quality education to the Filipino people. It was never an easy task, but it entails a lot of hard work and perseverance.

Thematic Chart B

Varied Thoughts about the Educational System

\begin{tabular}{|c|c|c|}
\hline Participants & Responses & Subordinate Themes \\
\hline Teacher 1 & $\begin{array}{l}\text { "Focus tayo sa Lecheria IS, ang approach lang natin ay } \\
\text { printed modular, pag modular lang napakahirap kasi unang- } \\
\text { una nasa-sacrifice'yung quality." }\end{array}$ & $\begin{array}{l}\text { Quality Being } \\
\text { Sacrificed }\end{array}$ \\
\hline Teacher 3 & "Ang hirap ng system natin today." & Difficult \\
\hline Teacher 8 & $\begin{array}{l}\text { "Sa totoo lang mahirap, naiisip ko kasi ang sitwasyon ng } \\
\text { ating mga bata sa kasalukuyan." }\end{array}$ & \\
\hline Teacher 6 & $\begin{array}{l}\text { "Ang hirap kasi lahat tayo bago, lahat ginagawa natin ay, } \\
\text { alam mo'yun, 'yung parang trial and error tayo ngayon." }\end{array}$ & Trial and Error \\
\hline Teacher 10 & $\begin{array}{l}\text { "It has been a very challenging educational system that we } \\
\text { are now." }\end{array}$ & Very Challenging \\
\hline Teacher 4 & $\begin{array}{l}\text { "Kumbaga 'yung problem ay 'yung nagpapa-implement pero } \\
\text { the system itself ay wala naman problema kasi student- } \\
\text { learner centered." }\end{array}$ & $\begin{array}{l}\text { Problem with the } \\
\text { Implementers }\end{array}$ \\
\hline Teacher 7 & "May kulang sa sistema o sabihin na nating minadali." & Insufficient and Abrupt \\
\hline Teacher 11 & $\begin{array}{l}\text { "For me, educational system was not properly or carefully } \\
\text { plan to implement this distance learning." }\end{array}$ & Not Carefully Planned \\
\hline Teacher 5 & $\begin{array}{l}\text { "Pinilit naman ni DepEd mag-adapt din doon sa new normal, } \\
\text { kahit na biglaan." }\end{array}$ & Forcing Adaptation \\
\hline Teacher 9 & $\begin{array}{l}\text { "I think educational system focus on what we can help } \\
\text { students and parents to improve their way of living." }\end{array}$ & $\begin{array}{l}\text { Improving the Way of } \\
\text { Living }\end{array}$ \\
\hline Teacher 13 & $\begin{array}{l}\text { "The Educational system also has to cope up with the new } \\
\text { trends." }\end{array}$ & $\begin{array}{l}\text { Coping with the New } \\
\text { Trends }\end{array}$ \\
\hline Teacher 14 & $\begin{array}{l}\text { "For me, all of us, especially the departments and } \\
\text { organizations governing the educational system are doing } \\
\text { their best to improve our current state." }\end{array}$ & $\begin{array}{l}\text { Doing its Best to } \\
\text { Improve }\end{array}$ \\
\hline Teacher 15 & $\begin{array}{l}\text { "Ang ating bansa ay nagkaroon na rin ng } K-12 \text { program } \\
\text { kung saan ang Elementarya at Sekondaryang paaralan ay } \\
\text { patuloy pa ring nagsusumikap na maibigay ang kalidad na } \\
\text { edukasyon." }\end{array}$ & \\
\hline Teacher 12 & “...I commend DepEd for finding ways..." & Finding Ways \\
\hline Teacher 2 & $\begin{array}{l}\text { "Parang ideal "yung gustong ipagawa pero sa totoong buhay } \\
\text { ay hindi applicable lalo na sa nakararaming estudyante." }\end{array}$ & Not Feasible \\
\hline
\end{tabular}

Ultimately, the new normal in Philippine education is characterized by remote learning that heavily relies on the students' and their respective families' capabilities to sustain quality education with minimal to almost non-existent supervision from teachers due to the fact that many families cannot afford the technology for online connectivity (Marquez, 2020). The totality of the education system, the students, their parents and the teachers are experiencing a crisis brought about by the pandemic.

Even before the pandemic, the government fell short on providing adequate educational materials to public schools, it would then be hard for them to supply all the things needed by the students and teachers for distance learning during the pandemic. In addition, even if there was some way to provide them with laptops, smartphones, or tablets, the telecommunications infrastructure of the country is ill-equipped to cater to the internet connectivity needs of everyone (Dollanganger, 2020), especially those who reside in far-flung areas. As a result, physical learning modules are the modality of choice. Unfortunately, teachers are the ones who suffer the most because they are required to reproduce these modules in spite of tight budgets (Mercado, 2020). They are also compelled to distribute these learning modules that, in some instances, may take a four-hour motorcycle ride through rocky, muddy, or uneven terrain (Casilao, 2020).

Interview Question 3: What changes have you experienced with regards to your role as a teacher in the new normal?

The role of the teachers has continuously evolved over time. This is congruent with the education paradigm 
Rabina, L.

that is being implemented for a period of time. But this pandemic has abruptly brought a sudden shift in the role of teachers. Various methodologies have been adapted to keep up with the changing needs of the learners. The shift brought about uncertainties for the students, the parents and the teachers. Doubts as to how will learning continue during the time of pandemic is the concern of most teachers.

Thematic Chart C

Changing Roles of a Teacher in the New Normal

\begin{tabular}{|c|c|c|}
\hline Participants & Responses & $\begin{array}{c}\text { Subordina1 } \\
\text { Themes } \\
\end{array}$ \\
\hline Teacher 1 & $\begin{array}{l}\text { "Siguro from a teacher, ngayon kasi 'di ka naman nagtuturo, nagtuturo ka lang 'pag } \\
\text { may tanong... siguro ngayon more on teacher counselor." }\end{array}$ & $\overline{\text { Counselor }}$ \\
\hline Teacher 4 & $\begin{array}{l}\text { "Yung isa pa ay parang counselor na din kasi nagbibigay tayo ng mga payo kasi } \\
\text { super stressful sa mga students. 'Yung iba ay sa atin kumukuha ng hope..." }\end{array}$ & \\
\hline Teacher 2 & $\begin{array}{l}\text { "Parang ngayon ang role ko na lang talaga ay magbigayng instructions, as a teacher } \\
\text { hindi na ikaw 'yung ikaw ang nagbibigay ng information sa bata...parang self- } \\
\text { learning...Ang ibibigay ko ay 'yung gabay sa kung ano ang dapat nilang gawin.", }\end{array}$ & Facilitator \\
\hline Teacher 11 & $\begin{array}{l}\text { "I am now a facilitator, guide to the students, since parents are now task as a direct } \\
\text { facilitator to their child." }\end{array}$ & \\
\hline Teacher 15 & $\begin{array}{l}\text { "Malaking impact sa mga mag-aaral na may taong gumagabay sa kanila maliban sa } \\
\text { kanilang mga magulang." }\end{array}$ & \\
\hline Teacher 6 & $\begin{array}{l}\text { “...parang ngayon mas mahirap kasi hindi ka na maka-communicate sa mga } \\
\text { bata...Hindi mo din na } i \text {-express 'yung pagiging teacher mo." }\end{array}$ & $\begin{array}{l}\text { New Norm: } \\
\text { Teacher }\end{array}$ \\
\hline Teacher 7 & $\begin{array}{l}\text { "Unang-una 'yung pagpunta sa school...sa gabi pa lang naghahanda ka na kung ano } \\
\text { ang mga dadalhin mo, pero ngayon 'di na kailangan...kahit naka-short ka at blouse } \\
\text { pwede ka ng magturo." }\end{array}$ & \\
\hline Teacher 8 & $\begin{array}{l}\text { "Ngayon kasi dalawa na ang pinagpapaliwanagan mo e, bukod sa mga mag-aaral } \\
\text { pati na ang mga magulang din." }\end{array}$ & \\
\hline Teacher 14 & $\begin{array}{l}\text { "As for today, the number of roles we play were reduced to Module and Activity Sheet } \\
\text { Creators, Subject consultants, Class monitors and Output checkers and recorders. } \\
\text { They may be few but all those are quite difficult and laborious play an important role } \\
\text { in student development." }\end{array}$ & $\begin{array}{l}\text { Multifacete } \\
\text { Teacher }\end{array}$ \\
\hline Teacher 5 & $\begin{array}{l}\text { "Yung role natin as a teacher andun pa rin naman 'yun; 'yung paraan natin na } \\
\text { makapagturo sa mga bata...napaka-importante talaga ng values integration..." }\end{array}$ & $\begin{array}{l}\text { Normal } \\
\text { Teacher }\end{array}$ \\
\hline Teacher 9 & $\begin{array}{l}\text { "I also adjust my time for them because not all parents are available at daytime...I } \\
\text { understand them more and accommodate them though it's very late." }\end{array}$ & $\begin{array}{l}\text { A More } \\
\text { Understandi: }\end{array}$ \\
\hline Teacher 10 & $\begin{array}{l}\text { "I become more understanding sa bata...I become more diligent to learn new things." } \\
\text { "...with our present situation, I find time to understand that every individual face }\end{array}$ & Teacher \\
\hline Teacher 12 & $\begin{array}{l}\text { difficulty in every aspect of life. So, I find time understanding my learners even more. } \\
\text { I learned to give more considerations." }\end{array}$ & \\
\hline Teacher 13 & $\begin{array}{l}\text { "It is the way how we interacted both the parents and students. The parents now are } \\
\text { more engaged when it come to their child's academic performance." }\end{array}$ & Communical \\
\hline Teacher 3 & $\begin{array}{l}\text { "Sa tingin ko 'yung isa ay 'yung communication sa bata kasi nung nagfi-face-to-face } \\
\text { pa po tayo mahirap na po 'yung communication mas lalo po ngayon na printed } \\
\text { modular." }\end{array}$ & \\
\hline
\end{tabular}

In a blog written by Barron et al. (2021) for World Bank Blogs, they mentioned that there are two crucial factors that have shifted in the role of teachers during the pandemic. First, pedagogical adaptations have proven to be pivotal as the traditional lecturing in-person models do not translate to a remote learning environment. Teachers need to innovate methodologies to keep students engaged since they are learning from the comforts of their homes. Second, the pandemic has recalibrated how teachers divide their time between teaching, engaging with students, and administrative tasks. It has been hard for everybody, especially for teachers who need to be able to manage their time wisely to fulfill their duties.

Similarly, the experiences shared by the respondents of the study were the same to the article posted by Ryan Schaaf on September 16, 2020. He stated that teachers, from preparing a personalized curriculum for courses to being a content creator to mentoring students on real-world projects to ensure that they are job-proof and upskilling themselves to stay abreast of emerging technology and skills, today's educators dabble in many things. From being facilitators of learning, educators have also turned to be innovators.

Ways in adapting to the new normal in teaching varies from one teacher to another. The difference in the perception of the change of roles of teachers under the new normal may depend on their personal experiences. 
One article written by Spencer (2020), he quoted Sien Tierney who said that "There are teachers who teach in the traditional way. And there are great teachers who are also model learners. They learn with the kids. They do not feel like they have to know everything, but they have to show what great learning looks like,". Clearly, this reflects the changing role of teachers in the education system.

Interview Question 4: Do you think this new normal brought a shift in your values and perspectives? What are these changes?

Thematic Chart D

Improved Values and Perspectives as a Teacher

\begin{tabular}{|c|c|c|}
\hline Participants & Responses & Subordinate Themes \\
\hline Teacher 1 & $\begin{array}{l}\text { "Yes...pagdating sa mga values maraming mga values ang na develop sa akin } \\
\text { ngayon, unang-una 'yung patience, 'yung pagiging considerate, tapos 'yung } \\
\text { concern, mercy, compassion sa mga bata. Sa perspectives, nabago sa akin nito, } \\
\text { mas nalilikot ko ang isip ko to suggest...kung hindi tayo mag-e-explore ng mga } \\
\text { bagay-bagay, ng mga strategies, hindi tayo mag-i-improve sa school... 'yung } \\
\text { pagiging risk taker." }\end{array}$ & $\begin{array}{c}\text { Patience, More } \\
\text { Consideration, Exploring } \\
\text { New Things and Strategie } \\
\text { and Risk-taking }\end{array}$ \\
\hline Teacher 2 & $\begin{array}{l}\text { "Oo, parang mas nagco-consider na ako sa mga bata ngayon kahit nalate ka, } \\
\text { sige kailangan habaan ang pasensya, magbibigay ng konsiderasyon." }\end{array}$ & $\begin{array}{l}\text { More Consideration and } \\
\text { Longer Patience }\end{array}$ \\
\hline Teacher 3 & $\begin{array}{l}\text { "Yes, siguro 'yun nga po, ang isa sa mga changes ay 'yung communication, } \\
\text { pagbibigay ng different activities, lalo lap o ngayon sa Grade 9." }\end{array}$ & $\begin{array}{l}\text { Communication and Givir } \\
\text { More Activities to Studen }\end{array}$ \\
\hline Teacher 4 & $\begin{array}{l}\text { "Madami. Sa values, mas humaba ang pasensya sa mga kabataan na sa face- } \\
\text { to-face maikli lang..." }\end{array}$ & Longer Patience \\
\hline Teacher 5 & $\begin{array}{l}\text { "Number } 1 \text { 'yung values ko, siguro napatingin ako sa health care... siguro 'yung } \\
\text { health muna natin. Health is wealth. Sa pagtuturo naman, mas pinahalagahan } \\
\text { ko ang work natin as a teacher." }\end{array}$ & $\begin{array}{l}\text { Giving Importance to Heal } \\
\text { and Valuing Work More }\end{array}$ \\
\hline Teacher 6 & $\begin{array}{l}\text { "Parang 'yung ngayon parang mas lalo kang magiging committed sa kanila, } \\
\text { (mga students) mas lalo mo silang ipu-pursue." }\end{array}$ & More Committed \\
\hline Teacher 7 & $\begin{array}{l}\text { "Sabi ko nga kanina, 'yung makukulit na estudyante na paulit-ulit, mas naging } \\
\text { mapagpasensya ka...Patience sa mga estudyante, sa pagsu-submit nila ng mga } \\
\text { output na kailangang unawain mo. 'yung understanding mo sa kalagayan nila." }\end{array}$ & Longer Patience \\
\hline Teacher 8 & $\begin{array}{l}\text { "Siguro sa pagtuturo hindi naman s'ya nabago kundi nadagdagan, kasi } \\
\text { kailangan natin ng malawak na pagtanggap sa kakayahan ng bata, pagtanggap } \\
\text { sa kakayahan ng mga magulang at saka po 'yung malawak na pang-unawa." }\end{array}$ & More Understanding \\
\hline Teacher 9 & $\begin{array}{l}\text { "I become more human especially in checking their output. We cannot blame if } \\
\text { their output are not what we are asking for." }\end{array}$ & More Human \\
\hline Teacher 10 & $\begin{array}{l}\text { "Definitely, this brought a lot of changes about my values and perspectives. Its } \\
\text { broaden about my perspectives po when it comes to, sa pagle-learn, "yun nga } \\
\text { po sa pagle-learn ng mga bagong kaalaman at understanding sa bata." }\end{array}$ & Broader Perspectives \\
\hline Teacher 11 & $\begin{array}{l}\text { "Yes. ... standards are not accurately followed because we need to give } \\
\text { considerations among students who were not able to cope and sustain the new } \\
\text { normal style of education." }\end{array}$ & More Consideration \\
\hline Teacher 12 & $\begin{array}{l}\text { "Yes, it does. This pandemic taught me how to be more understanding, be more } \\
\text { considerate, and be thankful." }\end{array}$ & $\begin{array}{l}\text { More Understanding and } \\
\text { More Thankful }\end{array}$ \\
\hline Teacher 13 & $\begin{array}{l}\text { "I am a caring and loving person even before the pandemic. So what happened } \\
\text { now is that I care a lot more not only to my family but to my students.." }\end{array}$ & More Caring \\
\hline Teacher 14 & $\begin{array}{l}\text { "A change in the current situation will definitely shift one's values and } \\
\text { perspectives. As for me, I have always been grateful for all the blessings but I } \\
\text { realized that sometimes, I tend to take some things for granted. Now, I have } \\
\text { learned to complain less and appreciate more." }\end{array}$ & $\begin{array}{l}\text { Complaining Less and } \\
\text { Appreciating More }\end{array}$ \\
\hline
\end{tabular}

The abrupt closure of schools around the globe due to the pandemic forced teachers to transition their methodologies from face to face to completely virtual. In most cases where children do not have access to technology, the modular approach in distance learning was utilized. The responsibility of communicating with the parents and learners depends on the teachers. Having this scenario, a shift in their values and perspective occurs. In the same way, the answers shared by the co-researchers of the study were the same with the experiences posted on the Internet through a blog written by Heubeck (2020). To wit, it leads to a question, "how has the shift to remote learning changed you as a teacher, for better or worse?" The following are the responses posted in the article:

Comment No. 1 "I can wholeheartedly say that the change has been, and will be, for the better. I will never again take for granted the student showing up for class early to tell me about their weekend or the student sitting in the back of the room trying to stay under the radar because they are having a bad day. These relationships are the foundation of the classroom and just so challenging in the remote world." 
Comment No. 2 "Remote learning has served as a vehicle for me to become a more well-rounded teacher, and it has opened my eyes to the extremely difficult situations that some of our students face. It also has given me a new appreciation for the simple ability to go in to work and be with my students and colleagues."

Comment No. 3 "I think it's made me a better teacher already. I've always thought of myself as an innovator. This has really pushed the innovation envelope."

Comment No. 4 "In the long run, on the other side of this, I'll be a better teacher, and human, overall. I have more empathy for life outside of school, and I have more trust in my students and what they're capable of."

As teachers work to construct their identities, they have no choice but to pick up the discursive tools that are available to them. Therefore, many teachers define their core motivation for becoming or remaining in the profession as the capacity to make a difference in the lives of children and help individuals achieve lifelong success (Jones et al., 2020). It has always been the commitment of teachers to educate the learners regardless of the situation. To contribute to the success of their students gives them a sense of accomplishment.

Interview Question 5: How do you think this shift in values and perspectives impact the quality of your work?

Thematic Chart E

Mixed Effects on the Quality of Teaching in the New Normal

\begin{tabular}{|c|c|c|}
\hline Participants & Responses & Subordinate Themes \\
\hline Teacher 1 & $\begin{array}{l}\text { “...mas effective ako 'pag nagtuturo ako sa loob ng classroom. Nandun 'yung quality. Nagagawa } \\
\text { ko 'yung best.” }\end{array}$ & $\begin{array}{l}\text { More Effective to Teach in t } \\
\text { Classroom }\end{array}$ \\
\hline Teacher 2 & $\begin{array}{l}\text { "Sa quality ng teaching syempre hindi ganun ka-effective kasi hindi tayo nagtuturo. Hindi ganun } \\
\text { ka-productive..." }\end{array}$ & Not that Effective \\
\hline Teacher 4 & $\begin{array}{l}\text { "Since WFH (work from home) pa rin tayo, malaking impact sa bahay lalo mahirap gumawa...so } \\
\text { mas wala po tayong natatapos minsan or minsan kailangan ng ipasa." }\end{array}$ & Difficult to Accomplish \\
\hline Teacher 5 & $\begin{array}{l}\text { "Ang perspective ko, tulungan...ako at ang mga magulang kasi gumagawa din ng paraan ang } \\
\text { mga magulang para maitawid nila ang pag-aaral ng kanilang anak. Nandito din ako para } \\
\text { gumabay." }\end{array}$ & Guiding the Parents \\
\hline Teacher 6 & $\begin{array}{l}\text { “...Kasi parang, pero in terms of quality of work, siguro masasabi ko na 'yung walang due date, } \\
\text { o hindi rush 'yung pinapagawa, pwede mong pag- efortan...'yung pag-iisipan mo talaga 'yung } \\
\text { ginagawa pero 'pag ang ginagawa mo halimbawa rush, parang 'yung quality of work mo ay } \\
\text { parang for compliance na lang...” }\end{array}$ & Flexible Work Schedule \\
\hline Teacher 7 & $\begin{array}{l}\text { "Siguro mas ano, 'yung trabaho mo ay mas napapahalagahan, saka maayos pa rin ang trabaho, } \\
\text { gagawin mo pa rin ang best e, kasi lalo na ngayon online. Kahit nandito tayo sa sitwasyon na ito, } \\
\text { dapat maayos pa rin ang trabaho." }\end{array}$ & $\begin{array}{l}\text { Giving More Importance ts } \\
\text { Work }\end{array}$ \\
\hline Teacher 8 & $\begin{array}{l}\text { "Siguro ano e, hanggat kaya at kung ano 'yung maibibigay natin kahit lagpas man doon sa } \\
\text { trabaho natin. Kumbaga isaalang-alang natin 'yung welfare at pagkatuto ng mga bata." }\end{array}$ & $\begin{array}{l}\text { Prioritizing the Welfare an } \\
\text { Quality of Learning of the } \\
\text { Students }\end{array}$ \\
\hline Teacher 9 & $\begin{array}{l}\text { "Hindi na ako ganun ka-strict na teacher. Kung ano ang the best na maibibigay nila, tinatanggap } \\
\text { ko." }\end{array}$ & Being Considerate \\
\hline Teacher 10 & $\begin{array}{l}\text { "These are all challenging po but we have to embrace na lang po talaga. Kung may perspective } \\
\text { po tayo na positive talaga, it will also magiging cause, fruit, bunga ng ating ginagawa ay of } \\
\text { course ay positive one as well." }\end{array}$ & Being Positive \\
\hline Teacher 12 & $\begin{array}{l}\text { "These changes provided me an opportunity to be a better public servant. Being emphatic among } \\
\text { others is close to being kind-hearted." }\end{array}$ & Being Emphatic to Others \\
\hline Teacher 13 & $\begin{array}{l}\text { "I realized that I have to work well and do all the best that I can, because I am grateful that } \\
\text { despite pandemic, I still have a job which is my bread and butter." }\end{array}$ & $\begin{array}{l}\text { Working with Best Efforts a } \\
\text { Gratitude }\end{array}$ \\
\hline Teacher 14 & $\begin{array}{l}\text { "I can say that being a more responsible and mature version of myself, I could serve better as a } \\
\text { teacher." }\end{array}$ & More Responsible and Matu \\
\hline Teacher 3 & $\begin{array}{l}\text { "Parang 'yung quality of education bumaba. Parang 'yung rate ng pagkatuto ng bata, bumaba } \\
\text { po." }\end{array}$ & Declining Quality of Educati \\
\hline Teacher 11 & $\begin{array}{l}\text { "In the coming of years, if the trend of education still persists well, the quality of education will } \\
\text { suffer and continuously deteriorating." }\end{array}$ & \\
\hline
\end{tabular}

Shift in the education paradigm occurred during the course of the pandemic. Teachers had to adapt instantaneously to the current set-up in the education system. Distance learning needs to be implemented to ensure that learning must continue despite the pandemic. Not all teachers are equipped with the technical knowledge needed to make learning effective. Aside from that, teachers do not have a clearer view of what lies ahead. This uncertainty brought about different thoughts in the minds of the teachers. The stress level has gone up since they are battling in a new ground. Both seasoned teachers and newbies were forced to try various methods to see what worked best for them and for their students. 
As written on one of Texas A\&M Publications (2020), "We are not all in the same boat, but we are all in the same sea. Some by yacht, some by boat and some by clinging to whatever floats our way and fighting with all of our might." Teachers are sailing in uncharted waters and so do students. In the effort of getting the most of what education could offer, the quality of teachers' work is affected. Some of the participants responded positively while there are some co-researchers of this study who thought likewise.

Interview Question 6: How do you describe your situation as a teacher before/during pandemic?

Thematic Chart F

Teacher's Extra Challenging Tasks during the Pandemic

\begin{tabular}{|c|c|c|}
\hline Participants & Responses & $\begin{array}{c}\text { Subordinate } \\
\text { Themes }\end{array}$ \\
\hline Teacher 1 & $\begin{array}{l}\text { "Before the pandemic, kasi ako 'yung gusto ko nagtuturo... During } \\
\text { pandemic naman, napansin ko na mas maganda magtrabaho sa } \\
\text { school kasi pagdating sa bahay, hindi natin... mahirap ihiwalay, } i \text { - } \\
\text { identify 'yung work life balance." }\end{array}$ & $\begin{array}{r}\text { Difficult to Mana! } \\
\text { Work-life Balanc }\end{array}$ \\
\hline Teacher 2 & $\begin{array}{l}\text { "Noon mahirap din ang sitwasyon bilang guro, marami din tayong } \\
\text { trabaho e kaya lang parang 'yung mga gawain natin mas madali } \\
\text { nating nagagawa, natatapos... 'yung focus natin doon lang...unless } \\
\text { ngayon pag nandito lang tayo sa bahay hindi ka makapag- } \\
\text { concentrate." }\end{array}$ & Less Concentratic \\
\hline Teacher 3 & $\begin{array}{l}\text { "Noon kasi 'di ba almost everyday nagagawa ka ng DLL (Daily } \\
\text { Lesson Log) at nag-iisip ka ng different activities and strategies kung } \\
\text { paano mo tuturuan ang estudyante mo ngayon na parang gigising ka } \\
\text { lang, io-open mo si messenger..." }\end{array}$ & $\begin{array}{l}\text { Technology as th } \\
\text { New Normal } \\
\text { Medium of } \\
\text { Instruction }\end{array}$ \\
\hline Teacher 5 & $\begin{array}{l}\text { "Ang focus natin doon sa face to face more on sa bata, kung papaano } \\
\text { sila disiplinahin, paano ibibigay ang pinaka-topic...Tapos during } \\
\text { pandemic...kailangan talaga ma-monitor natin ang mga bata... } \\
\text { ngayon kasi more on technology." }\end{array}$ & \\
\hline Teacher 6 & $\begin{array}{l}\text { "Before the pandemic, teaching is more enjoyable... nakakaharap } \\
\text { natin mga estudyante natin...Pero ngayong pandemic, sobrang } \\
\text { hirap, kasi 'yung adjustment na ginawa natin, sobrang dami." }\end{array}$ & $\begin{array}{l}\text { A Lot of Difficul } \\
\text { Adjustments to D }\end{array}$ \\
\hline Teacher 8 & $\begin{array}{l}\text { "Noong dati syempre 'yung routine natin...Malaking pagbabago at } \\
\text { adjustment sa ating mga guro pero nandun na 'yung sinasabi nilang } \\
\text { kailangan nating yakapin ang pagbabago." }\end{array}$ & $\begin{array}{l}\text { Embracing the } \\
\text { Changes }\end{array}$ \\
\hline Teacher 9 & $\begin{array}{l}\text { "Before pandemic, as a teacher I am compassionate and also strict } \\
\text { when it comes to the deadline of my students output but during this } \\
\text { pandemic, I become more compassionate." }\end{array}$ & $\begin{array}{c}\text { More } \\
\text { Compassionate }\end{array}$ \\
\hline Teacher 12 & $\begin{array}{l}\text { "Before the pandemic, it's difficult because I have to wake up early } \\
\text { to go to school and teach. During the pandemic, it's even more } \\
\text { difficult...having a hard time accomplishing school tasks..." }\end{array}$ & More Difficult \\
\hline Teacher 13 & $\begin{array}{l}\text { "Before the pandemic...I could easily reach out the students who } \\
\text { were not able to attend the school regularly. In the new normal } \\
\text { situation, it is more difficult to instruct the students..." }\end{array}$ & \\
\hline Teacher 14 & $\begin{array}{l}\text { "Every day for me is like a new adventure since I have to deal with a } \\
\text { large amount of people personally and I have different tasks to do." }\end{array}$ & $\begin{array}{l}\text { New Adventure: } \\
\text { Have Different } \\
\text { Tasks to Do }\end{array}$ \\
\hline Teacher 15 & $\begin{array}{l}\text { "Ngunit nang magkaroon na nga ng hindi inaasahang sitwasyon } \\
\text { nagbago ang lahat...hindi mo alam kung natuto ba sila sa mga } \\
\text { ibinigay mong mga gawain...." }\end{array}$ & $\begin{array}{l}\text { Unexpected } \\
\text { Changes, Uncerta } \\
\text { about the Student } \\
\text { Learning }\end{array}$ \\
\hline
\end{tabular}

Teachers are used to performing various different roles, but this year they are confronted with the most difficult tasks of their careers. They are being asked to be public health specialists. Experts in technical assistance. Social workers to families reeling from the effects of layoffs and illness. Masters of distance learning and trauma-responsive educational practices. And they are being asked to take on these new responsibilities against a backdrop of rising COVID-19 cases in many parts of the country, looming budget cuts for many school districts, and a hyper-polarized political debate over the return to school (Kerr et al., 2020). Moreover, coping with the demands of the current education system has become an advocacy for teachers. They are trained to always make the most of every opportunity. Looking at the situation as an opportunity of change may somehow ease the burden of doing things differently. It may be quite difficult to change the pedagogical landscape that has been used before the pandemic, but teachers are resilient in coping with change.

Interview Question 7: What are you doing differently as a result of the new normal in education? 
Teachers may not be prepared in the set-up for the new normal but they stay committed to their oath of educating their learners. COVID-19 is just one of those circumstances that affect the teaching and learning process. There are various events that have transpired like calamities and natural disasters, but teachers remain resilient over time. They have proven that they find ways as to how they will deliver.

Thematic Chart G

Coping with the New Normal Education

\begin{tabular}{|c|c|c|}
\hline Participants & Responses & $\begin{array}{c}\text { Subordinate } \\
\text { Themes }\end{array}$ \\
\hline Teacher 2 & $\begin{array}{l}\text { "Marami akong natutunan sa technology ngayon compare sa } \\
\text { dati." }\end{array}$ & $\begin{array}{c}\text { Attained More } \\
\text { Knowledgea abou } \\
\text { Technology }\end{array}$ \\
\hline Teacher 5 & "Pangalawa, 'yung technology, dapat magaling ka talaga." & $\begin{array}{c}\text { Should be } \\
\text { Technology Litera }\end{array}$ \\
\hline Teacher 9 & $\begin{array}{l}\text { "I am not a techie person. I am not a gadget lover but because of } \\
\text { this new normal, I need to upgrade myself using technologies." }\end{array}$ & \\
\hline Teacher 3 & $\begin{array}{l}\text { "Nagbibigay pa rin ng mga lessons through PPT. Kung ano 'yung } \\
\text { best na pede mo gawin, activities para sa mga bata para matuto } \\
\text { po sila." }\end{array}$ & $\begin{array}{l}\text { Teaching and } \\
\text { Communicating th } \\
\text { Students with th } € \\
\text { Use of Technolog }\end{array}$ \\
\hline Teacher 6 & $\begin{array}{l}\text { "Yung tipong kakaharapin mo ang iyong mga estudyante via cp, } \\
\text { via computer lang, unlike dati na face to face." }\end{array}$ & \\
\hline Teacher 13 & $\begin{array}{l}\text { "...call and explain the lessons to the students... must be a one-on- } \\
\text { one talk via messenger or cellular phones..." }\end{array}$ & \\
\hline Teacher 7 & $\begin{array}{l}\text { "Hindi ka pwedeng tumaliwas sa agos ng ilog e, kailangang } \\
\text { sumabay ka na, kung hindi maiiwanan ka." }\end{array}$ & $\begin{array}{l}\text { Embracing the Ne } \\
\text { Modality }\end{array}$ \\
\hline Teacher 8 & $\begin{array}{l}\text { "Kailangan mag-adjust tayo dun sa pagbabago. Ito po talaga tayo } \\
\text { e. Ito po talaga tayo bilang mga guro." }\end{array}$ & \\
\hline Teacher 10 & $\begin{array}{l}\text { "It takes a lot of time para mag-craft po tayo ng lesson natin for } \\
\text { our learners." }\end{array}$ & Time-Consuming \\
\hline Teacher 14 & $\begin{array}{l}\text { "..instead of going to school and teaching personally, we make use } \\
\text { of self-learning modules and activity sheets." }\end{array}$ & $\begin{array}{l}\text { Use of Self-learnir } \\
\text { Modules and } \\
\text { Activity Sheets }\end{array}$ \\
\hline Teacher 11 & $\begin{array}{l}\text { "...daily routine of teaching learning process really change...full } \\
\text { classroom management was out of the process..." }\end{array}$ & $\begin{array}{l}\text { Change in Daily } \\
\text { Routine }\end{array}$ \\
\hline Teacher 12 & $\begin{array}{l}\text { "I finish other school tasks at night when everybody in the house } \\
\text { is sleeping. There's really big difference in my routines before and } \\
\text { now." }\end{array}$ & \\
\hline Teacher 15 & $\begin{array}{l}\text { “...makilahok sa mga seminars and trainings upang mas lalong } \\
\text { mapaghandaan ang lahat ng gagawin ngayon new normal." }\end{array}$ & Attending Webina \\
\hline Teacher 1 & $\begin{array}{l}\text { "Tapos 'yung consideration... ngayon sobrang dapat mong } \\
\text { habaan, kumbaga may self-development, development of } \\
\text { patience." }\end{array}$ & $\begin{array}{l}\text { More Consideratio } \\
\text { Self-developmen } 1 \\
\text { Development of } \\
\text { Patience }\end{array}$ \\
\hline
\end{tabular}

The responses shared by the co-researchers of this study are similar to the experiences of those who are interviewed in an article written by Heim (2020). The responses were as follows:

Comment No. 1 "Should I accept those limits or should I embrace the potential and leverage my creativity to create promising outcomes? I have chosen the latter."

Comment No. 2 "Yet I worried about students in successive classes touching the same books. So, I went on Amazon and ordered three large boxes of nitrile gloves. I've placed a pair for every student in a baggie with her or his name on it, and the baggies are stored in separate boxes in the classroom. The students enter the room, wipe down the desks I have sprayed with liquid cleaner, wash their hands with sanitizer, grab the assigned baggie, put on the gloves, grab the book on the desk, read and at the end of class put the gloves in the baggie and the baggie in the box. A terribly makeshift solution, but one that's been enthusiastically received and executed by the students. They and I each do what we need to do - that's the can-do spirit of an American."

Comment No. 3 "Exhausted. That's the best way to describe how I've felt these last four weeks. Exhausted but also kind of excited. This unfortunate circumstance has in a weird way allowed me to really try some new things ..." 
Comment No. 4 "One of the ways I try to keep them engaged is through social media. I make TikToks about my trips and also post about them on Instagram and Twitter. I have a weekly contest where I post a video about an upcoming trip with clues. The first person to correctly guess where my next destination will be gets a prize I pick up fromthe gift shop and ship to them."

Comment No. 5 "My early thought process was about making this experience safe and wonderful for my students. Now that we're settling into this new way of life, I want to do everything I can not to lose this opportunity - not just for them but for myself. Keeping us all safe and healthy and learning is hard, hard work, but I'm focused and determined to give it my all. My efforts are guided by Maria Montessori's statement that "The child is both a hope and a promise for mankind."

Things may be done differently nowadays but the goal remains to be the same, that is to deliver quality education among the learners of the society.

Interview Question 8: How have you adjusted to the current situation of education in the new normal?

Thematic Chart H

Adjustments in the New Normal Education

\begin{tabular}{|c|c|c|}
\hline Participants & Responses & Subordinate Themes \\
\hline Teacher 1 & $\begin{array}{l}\text { “...sa puntong ito hindi pa ako adjusted kasi unang-una pati naman ang DepEd hindi } \\
\text { pa din naman adjusted. Marami pa tayong mga strategies na dapat e-explore." }\end{array}$ & Not Yet Fully Adjusted \\
\hline Teacher 3 & $\begin{array}{l}\text { "Sa totoo lang po ay hindi pa talaga adjusted...Pero syempre, teacher ka, kailangan } \\
\text { gawin mo ang best mo para matuto ang estudyante mo." }\end{array}$ & \\
\hline Teacher 13 & $\begin{array}{l}\text { "I am not a hundred percent adjusted....the Department of Education has always } \\
\text { something new...I am flexible enough to what the DepEd urges us to do." }\end{array}$ & \\
\hline Teacher 4 & $\begin{array}{l}\text { “...nasa process pa rin ng adjusting e, pwedeng sabihin na naka-adjust na kahit } \\
\text { papaano, kasi nakaka-moving forward naman tayo." }\end{array}$ & $\begin{array}{l}\text { Still in the Process of } \\
\text { Adjustment }\end{array}$ \\
\hline Teacher 6 & $\begin{array}{l}\text { "...kasi hanggang ngayon nag-a-adjust pa tayo. Parang... siguro dahil 'yun ang } \\
\text { hinihingi sa atin ng panahon." }\end{array}$ & \\
\hline Teacher 7 & "Nakakapag-adjust na as far as I am concern, kasi natututo e... unti-unti natututo." & \\
\hline Teacher 8 & $\begin{array}{l}\text { "Nag-a-adjust pa rin po, kasi iba-iba naman po e. ...kasi araw-araw iba naman po } \\
\text { ang mga gawain natin." }\end{array}$ & \\
\hline Teacher 15 & $\begin{array}{l}\text { "Sa ngayon nasa punto pa rin ako ng pag-aadjust... Oo mahirap pero para sa bata at } \\
\text { para sa bayan ay walang imposible." }\end{array}$ & \\
\hline Teacher 5 & $\begin{array}{l}\text { “...siguro mga nasa } 75 \% \text { pa lang. Makahanap tayo ng iba't ibang klaseng technique } \\
\text { kung paano ang bata ay ganito, ganyan, lalo na ngayon..." }\end{array}$ & $75 \%$ Adjusted \\
\hline Teacher 10 & $\begin{array}{l}\text { “...it takes a lot of adjustment po... ang ginagawa ko po is that I go with the flow... have } \\
\text { a proper time management... have an open mind po to be able to learn more 'yung mga } \\
\text { platforms, different platforms po." }\end{array}$ & Going with the Flow \\
\hline Teacher 11 & $\begin{array}{l}\text { "...help of the constant attending series of webinars. I gradually adapted the said new } \\
\text { normal in education." } \\
\text { "At first it was really difficult }\end{array}$ & Gradually Adapted \\
\hline Teacher 12 & $\begin{array}{l}\text { but through proper time management and setting of goals, I can say that I have } \\
\text { adjusted myself dealing with the current situation." }\end{array}$ & Adjusted \\
\hline Teacher 14 & $\begin{array}{l}\text { "It has been more than a year and I must say that I have adjusted to the current } \\
\text { situation. It is a slow and difficult process but we have no other choice but to get used } \\
\text { to it." }\end{array}$ & \\
\hline Teacher 9 & $\begin{array}{l}\text { "Very adjusted...very adjusted talaga... maybe because I become a more Godly- } \\
\text { centered person and more optimistic..." }\end{array}$ & $\begin{array}{l}\text { Fully Adjusted, More } \\
\text { Godly-Centered Person, } \\
\text { More Optimistic }\end{array}$ \\
\hline
\end{tabular}

The Department of Education has adapted the use of the Basic Education Learning Continuity Plan for the school year 2020-2021. This leaves the teachers with the responsibility of adapting to the changes brought about by the new normal in education. As teachers traverse the road of uncertainties, the choice they have affects the quality of services rendered. "Whatever is happening in the country; whatever challenges we are facing, education must continue. Education cannot wait; our learners cannot wait. We continue with the process so we can give hope and continuity, and contribute to the normalization of activities in the country," the Secretary recounted part of the speech on the High-Level Social Development Goals Action Event on Education she presented at the United Nations in New York City on June 28, 2017. Having this in mind, teachers need to reassess themselves and have a clearer understanding of what to adopt and how to adapt. 
The pandemic has pushed the education sector to adopt digitization and think beyond the usual classroom teaching to provide universal access to quality education (Saxena, 2020). The most obvious change has been learning shifting from the classroom to the home, with technology needing to be adopted and improved to accommodate the changes brought about by the pandemic. Teachers need to adopt various strategies to motivate students to continue learning.

In addition, Lexia (2020) from Cambium Company published an article that states, while educators continue to adjust to the change, they should remember to treat themselves with the same compassion they show to students and families. By maintaining personal connections, establishing routines, and reimagining timelines, educators can create stability and support for themselves and their students-including those who belong to the most vulnerable populations. It may not be easy to adapt to the things being done differently but surely nothing is impossible for a person that is much willing to bend for the sake of the many.

Interview Question 9: How does this shift affect you personally?

\section{Thematic Chart I}

\section{Effects of the Shift on the Teacher's Life}

\begin{tabular}{|c|c|c|}
\hline Participants & Responses & Subordinate Themes \\
\hline Teacher 1 & $\begin{array}{l}\text { "Nakaka-stress.Maraming distractions. Mas maganda mag-trabaho sa labas, sa } \\
\text { mismong workplace kasi yung work life balance mahirap talaga i-maintain." }\end{array}$ & Stressful, Many Distractio \\
\hline Teacher 2 & $\begin{array}{l}\text { "Actually, may time na nade-depress ako lalo na 'yung nagkakasabay-sabay ang } \\
\text { trabaho natin." }\end{array}$ & Depressed, Loads of Wor \\
\hline Teacher 4 & $\begin{array}{l}\text { "Personally, in a negative side, 'yung private time ko po ay nawawala, saka 'yung } \\
\text { time sa pagpapahinga, para mag-unwind, matanggal ang stress kahit papano." }\end{array}$ & $\begin{array}{c}\text { Compromising Private Tin } \\
\text { and Rest }\end{array}$ \\
\hline Teacher 6 & $\begin{array}{l}\text { “...siguro, positive, ay parang ang nangyari ay yes andito ka sa bahay, kasama mo } \\
\text { ang family mo. Kaso in a negative way, kapag tayo ay nahihingan ng reports, alam } \\
\text { mo 'yun, "yung binigay sayo kaninang umaga, tapos mayang hapon din ang pasa." }\end{array}$ & Quick Deadlines \\
\hline Teacher 7 & $\begin{array}{l}\text { "Nagkaroon din ng ano, siguro sa akin parang nalungkot, in a way na-depress, kasi } \\
\text { 'di ka na pumapasok...'di mo nakikita, nakakausap 'yung mga kasamahan mo... na } \\
\text { kahit walang kakwenta-kwenta ang pinag-uusapan natin... masaya tayo." }\end{array}$ & Sad, Depressed \\
\hline Teacher 5 & "Personally number 1 nabago 'yung daily routine natin." & Changed Daily Routine \\
\hline Teacher 11 & $\begin{array}{l}\text { "Really affect my personality, Stress triggers, in doing task...Physically unhealthy } \\
\text { sometimes..." }\end{array}$ & $\begin{array}{l}\text { Affecting Personality, } \\
\text { Triggering Stress, Becomi } \\
\text { Physically Unhealthy }\end{array}$ \\
\hline Teacher 15 & $\begin{array}{l}\text { "Nakakalungkot din dahil tayo ang inaasahan ng mga magulang at mag-aaral na } \\
\text { magbibigay ng sapat na kaalaman dahil nga sa limitado..." }\end{array}$ & $\mathrm{Sad}$ \\
\hline Teacher 8 & $\begin{array}{l}\text { "Ako, kumbaga, personal na nalulungkot kasi syempre may mga ganun tayong } \\
\text { nakikilalang tao...pero kumbaga wala tayo magawa." }\end{array}$ & \\
\hline Teacher 3 & "Parang mas lalong bumaba 'yung self-confidence..." & Lowering Self-confidenci \\
\hline Teacher 9 & $\begin{array}{l}\text { "Personally it's hard. Syempre I am used to teach face-to-face, seeing the } \\
\text { students." }\end{array}$ & Hard \\
\hline Teacher 10 & $\begin{array}{l}\text { "I become more innovative, personally po...more diligent po... have this positive } \\
\text { mind. I have to embrace na lang po these changes." }\end{array}$ & $\begin{array}{l}\text { More Innovative, More } \\
\text { Diligent, Having Positive } \\
\text { Mind, Embracing the } \\
\text { Changes }\end{array}$ \\
\hline Teacher 12 & “...helped me become a better person. I am more emphatic now." & $\begin{array}{l}\text { Becoming a Better Persor } \\
\text { More Emphatic }\end{array}$ \\
\hline Teacher 13 & $\begin{array}{l}\text { "A lot of fears came along... I shifted these fears into courage...became more } \\
\text { devoted in praying and asking the Almighty One to end this pandemic." }\end{array}$ & More Devoted in Prayin६ \\
\hline Teacher 14 & $\begin{array}{l}\text { "I learned to become more mature and responsible, to be grateful, to always be } \\
\text { positive, to be a risk-taker, and to be brave enough to grab opportunities which I } \\
\text { know would improve my family's life. " }\end{array}$ & $\begin{array}{l}\text { Becoming More Mature, } \\
\text { Responsible, Grateful, } \\
\text { Postive, Risk-taker, and } \\
\text { Brave }\end{array}$ \\
\hline
\end{tabular}

This school year has been very challenging for the teachers. The abrupt change to distance learning and the current set-up of work from home has created a huge impact on how things used to be and how things should be done at present. There are a lot of things that teachers need to cope with to perform their duties as teachers and at the same time perform their obligations at home.

Associate Professor Matthew Kraft (2020) co-developed a survey to help school districts better understand and respond to teachers' experience working remotely due to the coronavirus pandemic. The results of the survey suggest that the sudden shift to remote teaching has created significant challenges for teachers' work and limited the degree to which students can engage in learning. Mid-career teachers- those most likely to have children at home-have particularly struggled to balance their work responsibilities with their home lives during the pandemic. And seasoned teachers are over three times more likely than early-career teachers to report being 
uncomfortable using the technological tools required for teaching at home.

The experiences of the participants are similar to those who were interviewed in an article written on the website of the Department of Education Division of Parañaque City. The interviewee responded:

Comment No.1 “No complain about it! It's mother's role. Besides, I am learning the technology side of it and find every day as a learning opportunity."

Comment No.2 "Making video lessons was not easy since I have to memorize everything and the recording and editing come with difficulty," and he added, "I even involve my family in the editing of my videos." But just like the famous maxim that goes "Our difficulty can be our greatest opportunity"

Comment No. 3 "This pandemic has taught me to become more prayerful and value health and life more than anything else."

Comment No. 4 "We are encouraged to practice honesty, integrity and professionalism while in the performance of service whether it be physical reporting or WFH alternative arrangement."

According to Robosa et al. (2021), the stress teachers that go through when utilizing technology also depicts the increase in anxiety. Teachers are susceptible to know that the new learning model has shifted to online forms. The study revealed that many teachers who are not within the "Millennial" and Gen Z timeframe are more prone to distress. "Teachers do not situate well in blended forms of learning" this is what a study on online learning states on the problems in the classes. Teachers are not trained or educated to teach virtually, so blended learning is not their normative teaching platform. This confusion causes distress and frustration across the educating community. They also stated that there is a case study on the stress state of teachers and students in Stockholm, Sweden, which revealed that any sudden change in the learning environment causes disparity and even depression across teachers. This is particularly amongst the administrative heads of educational institutions. Almost 9 of 10 teachers feel incredibly stressed and anxious, following the shift caused by the pandemic.

Additionally, the survey report also revealed that $81 \%$ of the educators who were respondents of the study are putting in more than 14 hours a day to finish their professional responsibilities. UNICEF Thailand, (2020) recently published a forthcoming article discussing the adjustments teachers and students are currently undertaking given the pandemic's current situation. It was also concerned that health and education are two critical ideas that must not overlap each other. A study conducted by the University of Pennsylvania (2016) showed that stress levels might negatively affect teachers' efficacy and ability to educate students properly. Mental and emotional distractions were found to cause improper anger management and procrastination amongst teachers. According to a study-based report, teachers in the new normal would have to employ new practices and forms of management both professionally and emotionally to adapt to the virus outbreak changes fully. The report provided a structured timeline for response management, such as guidance, utilizing technology, and forming digital re-creational activities. A study surveying the impact of the virus pandemic on the general population showed that the most implicated the most affected populace are educators.

Accordingly, Canonizado (2020) pointed out that teachers cannot teach the lesson the way they used to teach. The majority of parents prefer written modules as an effective way of learning. Teachers' function is typically limited to planning modules, distributing and retrieving modules, answering parents' questions, and correcting learners' responses. Based on these, it is obvious that there is no contact with the learners. In the absence of a teacher, the learners study their lessons all by themselves. The new set-up may be challenging to teachers, but as usual they respond with resilience and rise above any circumstances. It is undeniably difficult to balance various tasks and responsibilities but embracing the change that has come about may lead to a better understanding of what lies ahead.

Interview Question 10. How do you handle the impact of the shift of values and perspectives brought about 
Rabina, L.

by the new normal?

Thematic Chart J

Ways of Handling the New Normal Education

\begin{tabular}{|c|c|c|}
\hline Participants & Responses & $\begin{array}{c}\text { Subordinate } \\
\text { Themes }\end{array}$ \\
\hline Teacher 1 & $\begin{array}{l}\text { "Mas ini-improve ko pa, mas ina-apply ko pa...Sinu-sustain ko 'yung mga } \\
\text { bago kong learnings.'Yung mga bagay, mga strategies na dapat kong } i \text { - } \\
\text { suggest, mas pinag-aaralan ko pa. Hindi ko sinasarili...pinag-aaralan ko ang } \\
\text { mga proseso." }\end{array}$ & $\begin{array}{l}\text { Apply New } \\
\text { Strategies }\end{array}$ \\
\hline Teacher 2 & $\begin{array}{l}\text { "Syempre ina-adapt ko ang aking sarili sa current situation at natututo akong } \\
\text { mag-adjust." }\end{array}$ & $\begin{array}{l}\text { Adapt to Current } \\
\text { Situation }\end{array}$ \\
\hline Teacher 3 & $\begin{array}{l}\text { "Magbibigay ka ng more time sa estudyante mo...para matuto po talaga sila. } \\
\text { Gagawin mo ang best mo as a teacher in this new normal." }\end{array}$ & $\begin{array}{l}\text { Give More Time t } \\
\text { Students }\end{array}$ \\
\hline Teacher 5 & $\begin{array}{l}\text { "Willingness to adjust and willingness to learn, "yun lang sa tingin ko ang key } \\
\text { para maging successful tayo kasi lahat ng bagay nagbabago." }\end{array}$ & $\begin{array}{l}\text { Willingness to } \\
\text { Adjust and } \\
\text { Willingness to Lea }\end{array}$ \\
\hline Teacher 6 & $\begin{array}{l}\text { "Siguro wala kang dapat isipin o gawin kundi sumunod na lang. Being a } \\
\text { teacher kasi kailangan mag-comply ka sa pinapagawa sa atin. Kailangan pa } \\
\text { rin nating gawin kasi nga ito 'yung tungkulin natin." }\end{array}$ & Follow and Comp \\
\hline Teacher 11 & $\begin{array}{l}\text { "I gradually adjust the new trend and uplift my initiative to perform what is } \\
\text { best for me and my students without sacrificing the quality of education in my } \\
\text { simple way." }\end{array}$ & $\begin{array}{l}\text { Adjust and Uplift } \mathrm{t} \\
\text { Initiative to Perfor }\end{array}$ \\
\hline Teacher 7 & $\begin{array}{l}\text { "Nahahandle ko "to positively kasi sabi ko nga marami akong natutunan. } \\
\text { Naniniwala ako na this is not forever. This too shall pass." }\end{array}$ & $\begin{array}{l}\text { Handle the } \\
\text { Responsibilities wi } \\
\text { Positivity and } \\
\text { Learning }\end{array}$ \\
\hline Teacher 9 & "More on positive kasi sabi ko nga I always look for the brighter side..." & Have a Positive \\
\hline Teacher 10 & $\begin{array}{l}\text { "I think, you have just to have positive look in life, that's how to handle this } \\
\text { impact...just go with the flow, just have faith that these things will come to an } \\
\text { end po." }\end{array}$ & Outlook in Life \\
\hline Teacher 8 & $\begin{array}{l}\text { “...nagpapasalamat sa araw-araw tapos let God...hayaan natin ang Diyos na } \\
\text { kumilos. May plano ang Diyos. Pagtanggap lang talaga ang kailangan." }\end{array}$ & Thank and Let Gc \\
\hline Teacher 4 & $\begin{array}{l}\text { "...nag-i-spent po ako most of the time, sa ngayon po more on sa praying, } \\
\text { pagbabasa ng Bible." }\end{array}$ & $\begin{array}{l}\text { More Time to Pra } \\
\text { Read the Bible }\end{array}$ \\
\hline Teacher 14 & $\begin{array}{l}\text { "One thing that I have made stronger during this time is my faith in the } \\
\text { Almighty. I take advantage of my extra time." }\end{array}$ & Have Faith in Go \\
\hline Teacher 15 & $\begin{array}{l}\text { "Sa pamamagitan ng Social media ay ipinaparating ko sa aking mag-aaral } \\
\text { ang aking suporta at pagmamahal upang kahit papano ay maibsan ang hirap } \\
\text { nila sa kanilang pag-aaral." }\end{array}$ & $\begin{array}{l}\text { Use Social Media } \\
\text { Show Support an } \\
\text { Love for the } \\
\text { Students }\end{array}$ \\
\hline Teacher 12 & "I am more understanding and considerate, but I am more careful, too." & Be More \\
\hline Teacher 13 & $\begin{array}{l}\text { "Every single detail that was imparted and taught us must be practiced at this } \\
\text { difficult times. }\end{array}$ & $\begin{array}{l}\text { Understanding, } \\
\text { More Considerat } \\
\text { More Careful } \\
\text { Practice the } \\
\text { Learning at thes } 6 \\
\text { Diffult Times }\end{array}$ \\
\hline
\end{tabular}

Building resilience to the daily challenges of life is what everybody is working on. However, the threat that this pandemic has brought has not only caused teachers to be stressed with their own lives and their families, but also their deep concern about the learning and wellbeing of their students. Feeling anxious during times of crises is a natural reaction to change, especially when uncertainties cover what lies ahead.

In a research conducted by Fadli et al. (2020), they mentioned that teaching is a profession that is very dynamic in carrying out its work. Teachers are pushed to always change according to the situation, conditions and environment. This clearly describes the scenario of the education set-up at present. There are many changes that are taking place, it is the innate ability of teachers to cope with these changes that made them adapt to the fast-phased scenario of the education system.

Furthermore, Manalo et al. (2020) emphasized that the participants' positive well-being contributes to addressing the challenges of the new normal education. Encouraging outlook, self-confidence gained from encouragement and motivation, healthy lifestyle, and stress reduction allows them to continue performing their duties and responsibilities despite the challenges of these trying times. When teachers create a positiv environment and well-being among themselves, it could foster improved academic performance and promote social and emotional progress among students even outside the classroom (Loveless, 2020).

Likewise, they found that being flexible and adaptive to changes allows teachers to survive and still succeed. Teachers are engaged in a constant desire to learn which would contribute to the growth. Flexibility and adaptability are important qualities that every teacher must acquire. Effective teachers can adjust, change, and 
Shifting of values and perspectives in the new normal

modify teaching methodologies depending on the students' needs, availability of resources, and context of environment. They value students' achievement, rather than rigid practices (Christenbury, 2011).

Corollary Question 4. Based on the results of the study, what action plan may be proposed?

An action plan is critical in accomplishing goals because it will help teachers stay motivated and ensure that they are on track to complete their goal in a reasonable amount of time. In order for the teachers to be well more adjusted in this new normal situation, below are some proposed programs.

Table B

The Proposed Action Plan

\begin{tabular}{|c|c|c|c|c|c|c|}
\hline $\begin{array}{l}\text { AREA OF } \\
\text { CONCERN }\end{array}$ & OBJECTIVES & $\begin{array}{l}\text { STRATEGY/ } \\
\text { ACTIVITY }\end{array}$ & $\begin{array}{c}\text { TIME } \\
\text { FRAME }\end{array}$ & $\begin{array}{l}\text { PERSON(S) } \\
\text { INVOLVED }\end{array}$ & SOURCE OF FUND & $\begin{array}{c}\text { SUCCESS } \\
\text { INDICATORS }\end{array}$ \\
\hline \multirow[t]{4}{*}{$\begin{array}{c}\text { Faculty } \\
\text { Development } \\
\text { Program } \\
\text { (FDP) }\end{array}$} & $\begin{array}{l}\text { To capacitate teachers with } \\
\text { necessary } 21^{\text {st }} \text { Century } \\
\text { knowledge and skills } \\
\text { responsive to the needs of } \\
\text { students and of the society }\end{array}$ & $\begin{array}{l}\text { Conduct the following } \\
\text { Faculty Development } \\
\text { Programs: } \\
\text { School Learning Action } \\
\text { Cell (SLAC) }\end{array}$ & \multirow[t]{2}{*}{$\begin{array}{l}\text { Whole Year } \\
\text { Round } \\
\text { (monthly) }\end{array}$} & \multirow[t]{2}{*}{$\begin{array}{c}\text { Principal, } \\
\text { Head Teachers, } \\
\text { LAC Coordinator, } \\
\text { and } \\
\text { Teachers }\end{array}$} & $\begin{array}{l}\text { Maintenance and Other } \\
\text { Operating Expenses } \\
\text { (MOOE) } \\
\text { Canteen Share }\end{array}$ & $\begin{array}{r}100 \% \text { of teachers } \\
\text { attended the Facul } \\
\text { Development Progra }\end{array}$ \\
\hline & $\begin{array}{l}\text { To improve the teaching } \\
\text { performance of teachers }\end{array}$ & $\begin{array}{l}\text { In-Service Training } \\
\text { (INSET) }\end{array}$ & & & Donation & $\begin{array}{l}30 \% \text { of teachers } \\
\text { achieved "Outstandi } \\
\text { rating in their IPCR }\end{array}$ \\
\hline & & Mentoring & & & & \\
\hline & & Coaching & & & & \\
\hline
\end{tabular}

\begin{tabular}{|c|c|c|}
\hline \multirow[t]{2}{*}{$\begin{array}{l}\text { Partnerships } \\
\text { and linkages } \\
\text { with } \\
\text { stakeholders }\end{array}$} & $\begin{array}{l}\text { To increase the number of } \\
\text { stakeholders and their } \\
\text { participation rate in school } \\
\text { programs, projects, and } \\
\text { activities }\end{array}$ & $\begin{array}{l}\text { Establish Mentoring } \\
\text { Hubs in different nearby } \\
\text { barangays where } \\
\text { enrollees reside. }\end{array}$ \\
\hline & & $\begin{array}{l}\text { Recruit stakeholders to } \\
\text { become Community }\end{array}$ \\
\hline
\end{tabular}

become Community

SBM

Principle 1:
Leadership

and

Governance

Principle 2;

Curriculum

and

Instruction
To strengthen the systemic,

effective, and efficient

Learning Continuity Plan
Conduct Monitoring and Evaluation (M and $\mathrm{E}$ ) of

school academic programs, projects, and activities

Craft intervention programs based on the results of $\mathrm{M}$ and $\mathrm{E}$.

$\begin{array}{ccc}\begin{array}{c}\text { Whole Year } \\ \text { Round }\end{array} & \begin{array}{c}\text { Principal, } \\ \text { Head Teachers, } \\ \text { Coordinators, }\end{array} & \begin{array}{c}\text { Maintenance and Other } \\ \text { Operating Expenses } \\ \text { (MOOE) }\end{array} \\ \text { (weekly) } & \begin{array}{c}\text { Teachers and } \\ \text { Stakeholders, } \\ \text { Barangay } \\ \text { Officials, parents, } \\ \text { students }\end{array} & \text { Canteen Share } \\ & & \text { Donation }\end{array}$

Whole Year

Principal, Head Teachers,

Teachers and

Stakeholders,

Members of

Quality
Assurance,

Technical

Assistance,

Assistance,

Evaluation
Maintenance and Other Operating Expense

Canteen Share

Donation
One (1) Mentoring I per identified baran was established.

Three (3) stakehold per barangay wer recruited as Facilitators
Community Lear

\footnotetext{
Incentive and

Reward

To uplift the moral values and perspective of the

System for
Teachers
} pandemic

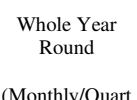

Principal,

Head Teachers

and
Teachers

Monthly/Qua
Maintenance and Other Operating Expenses (MOOE)

Canteen Share
Implementation o Implementation" rat in the review condus by $\mathrm{M}$ and $\mathrm{E}$
Committee.

Donation

$100 \%$ of teachers w recognized resultin६ uplifted moral valu and perspective. 


\section{Conclusions and Directions for Future Use}

\subsection{Consolidated Findings and Reflections}

Even before COVID-19, teachers play an important role in the lives of children. In addition to facilitating learning, teachers are key agents of socialization, helping students reach their highest potential and develop into good and responsible citizens. Caring, kindness, and emotionality are necessary parts of teachers' work. The central question of this study which focuses on the essence of lived experience of public secondary teachers in the new normal as to shifting of values and perspectives which was answered by the succeeding findings. Before the pandemic, teachers go about their day as usual as they used to. They wake up, go to school, teach their students, and fulfill the duties and responsibilities we are obliged to do. They have established a good rapport with their colleagues and share their knowledge and know-how with their co-teachers. Their unwavering dedication and hard work are unparalleled, it sometimes causes the, to set aside their own needs. Now that they are in this pandemic, though it may be tough and stressful for them, they still prioritize their students' needs above their own needs. Providing them with quality education is still their goal. This only proves that whatever difficulties and challenges that they may encounter, the student is their main priority and that they will not depart from our mission of educating the youth.

This phenomenological study acquired the lived experiences of fifteen (15) public secondary teachers of Lecheria Integrated School in the Division of Calamba City. The semi-structured interview of these participants focused on their experiences in terms of shifting of values and perspectives in the new normal. The participants in the study were unanimous in their responses with regards to their lived experiences in shifting of values and perspectives in the new normal and on how they are coping with it.

Similarly, the summarized findings from the responses in the interviews were discussed with theories and other research findings from the gathered literature. The significance of acknowledging these findings is that teachers will be able to understand that despite of all these challenges, still the commitment and dedication of being a teacher cannot be set aside. From this point of view of being a teacher, they can innovate, influence and openly embrace the new trends in this new normal in educating the students.

To further attest the abovementioned concepts, the following are the consolidated findings of the participants in terms of how their values and perspectives have shifted based on their lived experiences in the new normal. Most of the participants answered what they value the most in their profession is their students, commitment and dedication in their work, nobility of their profession and relationship with colleagues. These results served as a basis to emphasize how teachers' unwavering commitment to deliver quality education despite the circumstances. They expressed their opinions in various ways, but it boiled down to three core values which are commitment, integrity and dignity. They said that teaching is a noble profession and that being of service to their students is the most valuable thing that they have as a teacher. They are committed to give their utmost service to the students because they believe that the student's achievement is their achievement too. They also value integrity and dignity. They see to it that they walk the talk.

Conversely, in terms of their thoughts about today's educational system in the new normal, most of them mentioned that it is quite challenging. The participants in the study possessed similar responses in regard to their thoughts about the educational system. These results manifest that teachers are learning how adaptable and resilient educational systems, policy makers, teachers, students and families can be. That despite the overwhelming consequences of the pandemic, this global crisis has also been an extraordinary time for learning.

However, as regards to the role of a teacher in the new normal, the participants have varied answers. The roles they mentioned are counsellors, facilitators, new normal teacher, multifaceted teacher, normal teacher, a more understanding teacher; and lastly, communicator. The role of the teachers has continuously evolved over time. This is in consonance with the education paradigm that is being implemented for a period of time. But this

38 Consortia Academia Publishing (A partner of Network of Professional Researchers and Educators) 
pandemic abruptly brought a sudden shift in the role of teachers. Various methodologies have been adapted to keep up with the changing needs of the learners. The shift brought about uncertainties for the students, the parents and the teachers. Doubts as to how will learning continue during the time of pandemic is the concern of most teachers.

On the other hand, relative to the shift in teachers' values and perspectives brought about by these changes, most of the participants uttered about the improved values and perspectives as a teacher. The abrupt closure of schools around the globe due to the pandemic have forced teachers to transition their methodologies from face to face to completely virtual. In most cases where children do not have access to technology, the modular approach in distance learning was utilized. The responsibility of communicating with the parents and learners depends on the teachers. Having this scenario, a shift in their values and perspective occurs. Whereas, in connection to teacher's extra challenging tasks during pandemic, unanimously the participants had the same answers stating that it is more challenging to teach nowadays that people are experiencing this crisis unlike the past years.

In light of coping with the new normal education, most of participants noted that to cope with this crisis, teachers need to utilize the technology, to embrace the new modality, and to attend to webinars for it will be a big help to be more well-prepared in this new normal. In terms of the level of adjustments in the new normal education, some teachers already were adjusted to the current situation and some were not. According to them, they are all caught unaware, that whether they accept it or not, all of them will still be in the process of adjusting. Many people perceived the current coronavirus pandemic as a threat not only in health but in so many things.

With social distancing and quarantine as legal requirements in many countries, freedom is limited, likely leading people who are less afraid of health consequences to experience other negative emotions like anger or frustration. The participants' responses show that prioritizing the well-being of teachers a priority and providing them with proper programs and resources they need to be successful will result to healthier classroom environments for both the teachers and students

\subsection{Recommendations}

The COVID-19 pandemic has created the largest disruption of education systems in human history, affecting learners the world over. This has brought far-reaching changes in all aspects of our lives. Social distancing and restrictive movement policies have significantly disturbed traditional educational practices. Reopening of schools after relaxation of restriction is another challenge with many new standard operating procedures put in place.

Lockdown and social distancing measures due to the COVID-19 pandemic have led to closures of schools. There is a paradigm shift in the way educators deliver quality education - through various online platforms. The online learning, distance and continuing education have become a panacea for this unprecedented global pandemic, despite the challenges posed to both educators and the learners. Transitioning from traditional face-to-face learning to online or modular learning can be an entirely different experience for the learners and the educators, which they must adapt to with little or no other alternatives available. Likewise, teachers have been adjusting to the new pedagogical landscape as a different learning delivery modality has been implemented as stipulated in the Learning Continuity Plan. They have been doing everything to the fullest possible to cope with the new normal setup of educative process. The study provides these recommendations:

The call from the school support for professional development through the conduct of faculty development programs that will strengthen professional community among teachers to build a positive relationship with the organization of classes for learning and the academic performance of students.

The conduct of School Learning Action Cells (SLAC), In-Service Trainings (INSET), Mentoring and Coaching are imperative in order to capacitate the teachers with necessary knowledge and skills to be able to survive and thrive in the present teaching and learning process. 
$>$ The school shall invest in high-caliber speakers from different academic institutions and professional organizations who are expert on topics relative to the new normal educational system.

D Topics on mental health, stress management, and others that deal with health intervention programs should also be included in the faculty development program.

The need to maximize the community in delivering educational services to students by engagement of stakeholders that will play a crucial role in attaining a successful implementation of the school's programs and projects.

> Parents are actively involved from creating the LCP up to its implementation and evaluation.

Partnerships and linkages with the primary and secondary stakeholders should be fortified in order to help lessen the burden of teachers in implementing distance learning. And by doing so, academic concerns of all students can be accommodated and be given immediate purpose.

The school should establish mentoring hubs for parents in different barangays where learners reside.

> The stakeholders in the community such as retired teachers, education students, pre-service teachers, and other professional volunteers will serve as community learning facilitators who will mentor the parents in terms of the lessons and activities in the modules.

The two principles in the School-Based Management system should be given high priority in implementation: Leadership and Governance and Curriculum and Instruction.

> The Leadership and Governance wherein network of leadership and governance guide the education system to achieve its shared vision, mission and goals making them responsive and relevant to the context of diverse environment, and;

$>$ Curriculum and Instruction which wherein the curriculum learning systems anchored on the community and learners' contexts and aspirations are collaboratively developed and continuously improved. By empowering the effective and efficient implementation of these two equally important SBM principles, the entire school operation will surely be put in place that will help teachers be on the right direction in everything they do.

Incentive and reward system for teachers should be put in place. The role of teachers is a complex one. Today we are more concerned about the teacher instructive abilities. Teachers are expected to help students and to work in complex multicultural educational settings and to provide good educational experiences amidst the pandemic. Rewards can be in a form of appreciation, recognition, and benefit such as the entitlement of service credits. It is very important to motivate the teachers. However, the reward system should be explained clearly to make the teachers understand the connection between performance and reward for this is:

$>$ To motivate the teachers and to make their performance effective reward is very important; and

$>$ To develop the psychological contact and to develop a positive relationship in employment.

\section{References}

Allison, C. (2020). How to adjust to the new normal. Retrieved from https://healthmatters.nyp.org/how-to-adjust-to-the-new-normal/

Alvez, T., Paras, N., Perante, L., \& Robosa, J. (2021). The experiences and challenges faced of the public school teachers amidst the COVID-19 pandemic: A phenomenological study in the Philippines. International Journal of Advance Research and Innovative Ideas in Education, 7(1). https://doi.org/10.6084/m9.figshare.14028833.v1 
Shifting of values and perspectives in the new normal

Baker, C., Peele, H., Daniels, M., Saybe, M., Whalen K., \& Overstreet, S. (2021). The experience of COVID-19 and its impact on teachers' mental health, coping, and teaching. School Psychology Review. https://doi.org/10.1080/2372966X.2020.1855473

Barron, M., Cobo, C., Najar, A., \& Ciarrusta, I (2021). The challenging role of teacher and technologies amidst the COVID 19 pandemic: Key findings from a cross-country study. Retrieved from

https://blogs.worldbank.org/education/changing-role-teachers-and-technologies-amidst-covid-19-pande mic-key-findings-cross

Beloy, R. (2020). Department of Education, Division of Parañaque City. Retrieved from https://www.depedparanaquecity.com/wfh-a-journey-of-insightful-discoveries/

Bruce, J. (2018). Change is the new normal. How will you handle it? Retrieved from https://www.forbes.com/sites/janbruce/2018/09/05/change-is-the-new-normal-how-will-you-handle-it/?

Business Mirror. (2020). Filipino teachers and the passion that makes learning continuity possible. Retrieved from https://businessmirror.com.ph/2020/07/28/filipino-teachers-and-the-passion-that-makes-learning-contin uity-possible/

Canonizado, I. (2020). Challenges that teachers are facing under the new normal system in education. Retrieved from

https://discover.hubpages.com/education/Challenges-that-Teachers-Are-Facing-Under-the-New-Normal -System-in-Education

Casilao, J. L. (2020). Teachers in remote areas struggle to deliver modules. GMA News Online. Retrieved from https://www.gmanetwork.com/news/news/nation/751406/teachers-in-remote-areas-struggle-to-delivermodules/story/

Department of Education. (2019). Retrieved from https://www.deped.gov.ph/2019/11/20/briones-ensure-educational-continuity-amid-challenges/

Department of Education. (2020). Retrieved from https://www.deped.gov.ph/2020/05/06/official-statement-2/

Dussault, A. (2018). Top 8 Classroom Challenges, According to Teachers. Retrieved from https://www.classcraft.com/resources/blog/8-teacher-challenges-2018/

Fadli, F., Siti, I., \& Rukiyati, A. (2020). Techno - resilience for teachers: Concepts and action. Retrieved from https://www.temjournal.com/content/92/TEMJournalMay2020820825.pdf

Heim, J. (2020). Dispatches for education's front lines. Retrieved from https://www.washingtonpost.com/education/2020/10/07/teachers-pandemic-experience/

Hendricks, M. (2020). Adjusting to a New Normal: 5 Tips for Back-to-School This Year. Retrieved from https://blog.socialstudies.com/adjusting-to-a-new-normal-5-tips-for-back-to-school-this-year?

International Board of Credentialing and Continuing Education Standards (IBCCES). (2020). Retrieved from https://ibcces.org/blog/2020/07/10/stress-teachers-school

Jensen, E. (2017). 5 Ways to overcome the daily grind and stay passionate about your work. Retrieved from https://www.lendio.com/blog/small-business-tools/5-ways-overcome-daily-grind-stay-passionate-work/

Jones, A. L., \& Kessler M. A. (2020). Teachers' emotion and identity work during a pandemic. Front. Educ. 5, 583775. https://doi.org/10.3389/feduc.2020.583775

Kerr, S., \& Schwartz, N. (2020). Research and evidence can help guide teachers during the pandemic. Retrieved from

https://www.shankerinstitute.org/blog/research-and-evidence-can-help-guide-teachers-during-pandemic

Kraft, M., \& Simon, N. (2020). Teachers' Experiences Working from Home During the COVID-19 Pandemic. Retrieved from https://education.brown.edu/news/2020-06-25/teachers-experiences-working-home-during-covid-19-pa $\underline{\text { ndemic }}$

Kraft, M., Simon, N., \& Lyon, M. (2020). Sustaining a Sense of Success: The importance of teacher working conditions during COVID_19 Pandemic. Retrieved from https://www.edworkingpapers.com/sites/default/files/ai20-279.pdf

Lagua, B. (2020). Teaching in the New Normal. Retrieved from 
Rabina, L.

https://www.manilatimes.net/2020/10/30/business/columnists-business/teaching-in-the-new-normal

Loveless, B. (2020). Strategies for building a productive and positive learning environment. Retrieved from https://www.educationcorner.com/building-a-positive-learning-environment.html

Maiyani, N. (2017). Teacher commitment and dedication to student learning. Retrieved from https://ijrar.com/upload_issue/ijrar_issue_497.pdf

Manalo, F., \& Villa, J. (2020). Secondary teachers' preparation, challenges, and coping mechanism in the pre -implementation of distance learning in the new normal. International Multidisciplinary Research Journal, 2, 144-154. https://doi.org/10.5281/zenodo.4072845

Manila Bulletin. (2020). Teacher's Paradigm Shift in the New Normal. Retrieved from https://mb.com.ph/2020/10/04/teachers-paradigm-shift-in-the-new-normal/

Marquez, L. P., Olivar, M. V. V., Brijuega, C. E., Ombao, R. P., Cerio, W. C., \& Baes, F. D. (2020). Education and COVID-19: Experiences and insights from a developing country. ACCESS: Contemporary Issues in Education, 40(1), 84-90. https://doi.org/10.46786/ac20.5188

Mayzenberg, A. (2020). Accepting and adapting to a new normal for school. Retrieved from https://www.collegexpress.com/articles-and-advice/student-life/blog/accepting-and-adapting-new-norm al-school

Mercado, N. A. (2020). Some students have to share modules due to tight budget - DepEd. Inquirer. Retrieved from

https://newsinfo.inquirer.net/1335796/budget-woes-deped-says-some-students-have-to-share-modules-t his-school-year

Mitchell, M. (2015). Integrity in the classroom. https://www.psychologytoday.com/us/blog/the-moment-youth/201509/integrity-in-the-classroom

O'Sullivan, M. (2020). What about teachers' learning during COVID-19? Retrieved from https://www.wise-qatar.org/what-about-teachers-learning-during-covid19/

Olson, K. (2020). Tips for teachers in a pandemic. Retrieved from https://www.redlands.edu/bulldog-blog/2020/april-2020/tips-for-teachers-in-a-pandemic/

Osuba, A. (2020). Stress management for teacher: 16 Activities to Reduce Teachers' Stress. Retrieved from https://everfi.com/blog/k-12/strategies-to-support-stress-management-for-teachers/

Pezaro, S. (2018). Theories of work-related stress. Retrieved from https://sallypezaro.wordpress.com/2018/03/22/theories-of-work-related-stress/

Rayner, L. (2020). Self-care for teachers as they navigate the new normal. Retrieved from https://www.graduateprogram.org/2020/11/self-care-for-teachers-as-they-navigate-the-new-normal

Saxena, A. (2020). The changing role of the educator in the new normal. Retrieved from https://www.highereducationdigest.com/the-changing-role-of-the-educator-in-the-new-normal/

Schaaf, R. (2020). The new role of educators during and after COVID-19. Retrieved from https://thelearningcounsel.com/article/new-role-educators-during-and-after-covid-19

Tadas, P. (2019). The challenges faced by a teacher. Retrieved from https://timesofindia.indiatimes.com/readersblog/parimala/teachers-challenges4812/

The Graide Network. (2013). The rise of teacher stress. The Graide Network. Retrieved from https://www.thegraidenetwork.com/blog-all/2018/8/1/crayons-and-cortisol-the-epidemic-of-teacher-stre $\underline{\text { sS }}$

Torres, C. (2020). What is a teacher's role in “the new normal?”. Retrieved from https://inservice.ascd.org/what-is-a-teachers-role-in-the-new-normal-pandemic/

Vezner, H. (2020). Embracing change: Creating a new normal. Retrieved from https://www.cui.edu/academicprograms/education/perfecting-the-practice/blog/post/embracing-changecreating-a-new-normal

Yurcaba, J. (2020). How teachers are coping with the new realities of the COVID-19 classroom. Retrieved from https://www.verywellmind.com/teaching-struggles-during-covid19-5087307

42 Consortia Academia Publishing (A partner of Network of Professional Researchers and Educators) 